\title{
DRY BEAN (PHASEOLUS VULGARIS L.) CROP WATER PRODUCTION FUNCTIONS AND YIELD RESPONSE FACTORS IN AN ARID TO SEMI-ARID CLIMATE
}

\author{
Vivek Sharma ${ }^{1, *}$, Abhijit Rai ${ }^{2}$ \\ ${ }^{1}$ Department of Agricultural and Biological Engineering, University of Florida, Gainesville, Florida, USA. \\ 2 Department of Plant Sciences, University of Saskatchewan, Saskatoon, Saskatchewan, Canada. \\ *Correspondence: vsharma1@ufl.edu
}

\begin{abstract}
HighLIGHTS
- Deficit irrigation negatively affected dry bean yield and yield components.

- Excess irrigation increased crop $\mathrm{ET}_{c}$ but not dry bean yield.

- Soil moisture fluctuation was greater in the top $0.3 \mathrm{~m}$ of the soil profile compared to deeper depths.

- Crop water production function had a slope of $18.9 \mathrm{~kg} \mathrm{ha}^{-1} \mathrm{~mm}^{-1}$ and threshold crop evapotranspiration of $171 \mathrm{~mm}$.

- Dry bean crop was found to be sensitive to water stress (yield response factor $K_{y}=1.94$ ).
\end{abstract}

\begin{abstract}
Under changing climate conditions and declining water resources, understanding crop response to water stress is critical for effective irrigation management. The objectives of this study were to quantify dry bean (Phaseolus vulgaris $L$., cv. Othello) soil moisture dynamics, crop evapotranspiration (ET $)$, and yield response factor and to develop dry bean irrigation and crop water production functions (IWPF and CWPF). Five irrigation treatments, i.e., full irrigation (FIT), $75 \%$ FIT, $50 \%$ FIT, 25\% FIT, and 125\% FIT, were evaluated using a randomized complete block design (RCBD) with three replications for three years $(2017,2018$, and 2019) in the arid to semi-arid intermountain region of Powell, Wyoming. The results showed a significant influence of irrigation on dry bean soil moisture dynamics and ET. The dry bean crop showed a greater soil moisture fluctuation in the top $0.3 \mathrm{~m}$ of the soil profile compared to $0.6 \mathrm{~m}$ and at $0.9 \mathrm{~m}$. ET $T_{c}$ ranged from 187 to $438 \mathrm{~mm}$, from 190 to $409 \mathrm{~mm}$, and from 217 to $398 \mathrm{~mm}$ in the 2017, 2018, and 2019 growing seasons, respectively. A positive two-segment relationship was observed between dry bean seed yield and cumulative irrigation water applied. The average cumulative seasonal irrigation of $310 \mathrm{~mm}$ resulted in maximum seed yield. For all three years, the seed yield increased linearly with $E T_{c}$. Combining the data from the three years resulted in a CWPF with a slope of $18.9 \mathrm{~kg} \mathrm{ha} \mathrm{mm}^{-1}$ and an offset of $171 \mathrm{~mm}$ of $E T_{c}$ (i.e., the ET $T_{c}$ required for crop establishment before any seed yield is produced, or threshold $\left.E T_{c}\right)$. Moreover, the dry bean crop was found to be sensitive to water stress $\left(K_{y}=1.94\right)$. These results indicated that under the typical semi-arid to arid climate conditions of the intermountain region of Wyoming, deficit irrigation of dry bean may not be a viable strategy because the yield loss outweighs water-saving benefits.
\end{abstract}

Keywords. Dry bean, Crop evapotranspiration, Crop production function, Irrigation water production function.

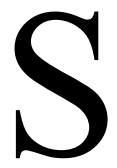

ustainable development of water resources for food production while minimizing the negative impact on the environment are the grand challenges of the 21 st century. Currently, nearly $70 \%$ of the global renewable water resources are used for irrigation (Dubois, 2011). The availability of water for irrigation is projected to decrease over time due to increasing climate variability, reduction in water quantity and quality, increasing competition for freshwater resources from other sectors of the economy, and

\footnotetext{
cc) $\$$ The authors have paid for open access for this article. This (c) ${ }_{\mathrm{BY}}$ NC ND work is licensed under a Creative Commons AttributionNonCommercial-NoDerivatives 4.0 International License https://creative commons.org/licenses/by-nc-nd/4.0/

Submitted for review on 19 March 2021 as manuscript number NRES 14582; approved for publication as a Research Article by the Natural Resources \& Environmental Systems Community of ASABE on 2 November 2021.
}

changes in water policy (Giorgi and Bi, 2005; Wilhite et al., 2007). The arid to semi-arid regions of the western U.S., including Wyoming, where crop and livestock production is a significant part of the economy, are experiencing water resource and irrigation allocation constraints. Although the Wyoming state constitution decrees that all water inside the state boundaries is property of the state, several interstate water compacts and court decrees limit the amount of streamflow that Wyoming can deplete (Jacobs and Brosz, 1995).

As Wyoming's agricultural, municipal, industrial, and recreational/environmental water uses increase, the state's limited water supplies have come under increasing scrutiny. In addition to this, the demand-supply balance is threatened by the non-uniform distribution of precipitation (Sharma et al., 2020), and the occurrence of extreme events like droughts (Wilhite et al., 2007). With inadequate precipitation during the growing season and high evaporative demand 
in the region, the productivity of major crops in the region is largely dependent on supplemental irrigation (Schwartz and Brick, 2015). In Wyoming, many producers are facing significant management changes (e.g., conversion from furrow to sprinkler irrigation) to conserve irrigation water resources. The adoption of sprinkler irrigation in Wyoming has increased by $50 \%$ from 1990 to 2013 (USDA-NASS, 2018). Under these scenarios, agricultural producers and their advisors, as well as state and federal water resource agencies, are challenged to practice water conservation and use water more efficiently while still meeting crop water requirements. A viable strategy to effectively manage these scenarios is to adopt effective irrigation management strategies such as deficit or limited irrigation to increase crop water productivity (CWP), also known as crop water use efficiency (CWUE).

Deficit or limited irrigation, which allows some degree of water deficit with minimal yield reduction, is a management strategy that has been widely accepted for optimizing water use in water-limited areas (Trout et al., 2020; Irmak, 2014; Djaman and Irmak, 2012; Payero et al., 2006, 2009; Pereira et al., 2002; English, 1990). The yield reduction is justified by the economic benefits derived from increased irrigation efficiency, reduced irrigation costs, and the opportunity costs of water (English, 1990). To devise an effective deficit irrigation strategy for a specific crop, it is essential to quantify the crop water needs and the magnitude of water deficit that the crop can sustain before significant yield reduction occurs. This requires a thorough understanding of the water balance components, soil moisture dynamics, yield response factor $\left(K_{y}\right)$, and water production functions.

The irrigation water production function (IWPF, i.e., the relationship between crop yield and cumulative irrigation water applied) and the crop water production function (CWPF, i.e., the relationship between crop yield and total seasonal $\mathrm{ET}_{c}$ ) can be jointly characterized as the water production function (Stewart and Hagan, 1973; Howell and Hiler, 1975; Howell et al., 1998; Trout and DeJonge, 2017; Trout et al., 2020). Many studies have reported a linear relationship between crop yield and $\mathrm{ET}_{c}$ (Irmak, 2014; Klocke et al., 2014). However, non-linear CWPFs were reported by Trout and DeJonge (2017). The linearity between crop biomass and water was first observed in the early 20th century by Briggs and Shantz (1913). However, the concept was first formalized by de Wit (1958). The difference in the water production function relationships (i.e., linear vs. curvilinear) can be expected, as many factors impact yield. Therefore, it is important to understand how the water production function of the same crop can vary under different conditions. In addition, these relationships are also helpful for optimizing the management of limited water resources, especially when yield is expressed as a function of irrigation water applied. This is especially important for a crop such as dry bean (Phaseolus vulgaris L.) in the semi-arid to arid region of Wyoming, where limited information is available.

The dry bean response to water stress can vary with cultivars and landraces (Lanna et al., 2016; Emam et al., 2012; Singh et al., 2009), soil type (Daryanto et al., 2015), frequency, duration, and intensity of drought stress (Rai et al., 2020; Muñoz-Perea et al., 2007), and climate. The effect of water stress includes visible symptoms of excessive reduction of flowers, number of pods, and seeds per pod during the pre-anthesis and reproductive growth stages (Rai et al., 2020). Intermittent to severe drought stress can significantly reduce biomass accumulation, harvest index, number of pods and seeds per pod, and days to maturity, and reduce seed yield by $20 \%$ to $90 \%$ (Rai et al., 2020; Nuñez Barrios et al., 2005; Terán and Singh, 2002; Nielsen and Nelson, 1998; Ramirez-Vallejo and Kelly, 1998; Stroker, 1974). Adequate irrigation management can substantially reduce these yield risks, increase water use efficiency, and conserve water.

Under water-stressed conditions, dry bean yields generally display a positive relationship with total seasonal water use. However, yield response to water use can vary with both location and time of the year depending on differences in climate and crop management conditions. Nielsen (2018) developed a CWPF for three dry bean cultivars using data collected at Akron, Colorado, from 1993 to 1998 and reported a linear relationship between dry bean seed yield and water use, with regression slopes ranging from 7.62 to $10.97 \mathrm{~kg}$ $\mathrm{ha}^{-1} \mathrm{~mm}^{-1}$ of water use. Yonts et al. (2018) reported a curvilinear relationship between dry bean yield and total seasonal water supply and stated that, in the semi-arid climate of western Nebraska, reducing irrigation by $25 \%$ in comparison to full irrigation increased irrigation water use efficiency (IWUE) by $26 \%$ and reduced seed yield by only $6 \%$. They further reported that dry bean seasonal irrigation requirement, $\mathrm{ET}_{c}$, and IWUE ranged from 224 to $421 \mathrm{~mm}$, from 362 to $432 \mathrm{~mm}$, and from 5.0 to $20.0 \mathrm{~kg} \mathrm{ha}^{-1} \mathrm{~mm}^{-1}$, respectively. They did not present $\mathrm{ET}_{c}$ data that could be used to construct the CWPF. A similar curvilinear relationship was observed by Miller and Burke (1983) in the Pacific Northwest for dry bean grown on sandy soils, and the researchers reported dry bean IWUE ranging from 16.2 to $17.4 \mathrm{~kg} \mathrm{ha}^{-1} \mathrm{~mm}^{-1}$.

Although no IWPF and CWPF were developed by AlKaisi et al. (1999), they reported that dry bean yield increased up to the irrigation rate of $1.33 \mathrm{ET}_{c}$ (crop evapotranspiration). However, no significant increase in seed yield at $0.67 \mathrm{ET}_{c}$ or greater was observed under drip irrigation in the wet year. The researchers measured dry bean $\mathrm{ET}_{c}$, irrigation requirement, CWUE, and IWUE as $414 \mathrm{~mm}, 371 \mathrm{~mm}, 9.7 \mathrm{~kg}$ $\mathrm{ha}^{-1} \mathrm{~mm}^{-1}$ of $\mathrm{ET}_{c}$, and $10.9 \mathrm{~kg} \mathrm{ha}^{-1} \mathrm{~mm}^{-1}$ of irrigation, respectively. In south-central Washington, Muñoz-Perea et al. (2007) tested six dry bean genotypes in a non-stressed and drought-stressed environment at the University of Idaho's Kimberly Research and Extension Center in 2003 and 2004. They reported seasonal dry bean water use and IWUE of 318 to $548 \mathrm{~mm}$ and 3.4 to $10.0 \mathrm{~kg} \mathrm{ha}^{-1} \mathrm{~mm}^{-1}$, respectively, under non-stressed conditions and 239 to $338 \mathrm{~mm}$ and 1.1 to $10.4 \mathrm{~kg} \mathrm{ha}^{-1} \mathrm{~mm}^{-1}$, respectively, under drought-stressed conditions. They further reported a $25 \%$ reduction in dry bean seed yield when irrigation was reduced by $65 \%$ in the milder growing season, in comparison to a $34 \%$ reduction when irrigation was reduced by $43 \%$ in the hotter growing season. Nielsen (2018) reported that the response of dry bean yield to water availability can vary from 5.0 to $24.4 \mathrm{~kg} \mathrm{ha}^{-1} \mathrm{~mm}^{-1}$ in the Central High Plains region of the U.S. depending on the soil, climate, agronomic practices, and cultivar.

The differences in reported dry bean response to water stress and its variability across the Central High Plains region limit its transferability to other areas. Therefore, there 
is a need for comprehensive irrigation studies that assess both soil-based and plant-based approaches to monitor water stress and quantify the crop response per unit of water used under progressive water stress and that will allow transferability and application of knowledge under similar climate conditions. For example, developing crop production functions can help producers and their advisors effectively adopt on-farm limited or deficit irrigation practices and perform economic comparisons of different local management practices, and help government agencies effectively plan and assess the water needs for the region. Similarly, an understanding of crop-available soil moisture can help producers and their advisors devise strategies that limit environmental losses and promote higher consumptive use. In addition to this, the relationship between yield components (seed weight, number of pods, and seeds per pod) and water stress can help understand photosynthate partitioning in response to water stress.

Hence, it is important to quantify the impact of deficit irrigation on dry bean growth, yield, yield components, soil moisture dynamics, and $\mathrm{ET}_{c}$, and to develop crop water production functions and crop response factors, especially in the arid to semi-arid climate of Wyoming, where no information is available. The region is witnessing a transition from surface to sprinkler irrigation, with a substantial risk of water limitation in the present and future. A companion study (Rai et al., 2020) presented the effects of water stress on dry bean growth characteristics, yield potential, and the interrelationship between them. The specific objectives of the present study were to: (1) quantify dry bean soil moisture dynamics and water use, i.e., evapotranspiration $\left(\mathrm{ET}_{c}\right)$, (2) develop dry bean $\mathrm{ET}_{c}$ and irrigation water production functions (CWPF and IWPF), and (3) develop a yield response factor $\left(K_{y}\right)$ for the intermountain west in response to different irrigation levels.

\section{MATERIALS AND METHODS}

\section{SITE DESCRIPTION}

Field experiments were conducted in 2017, 2018, and 2019 at the University of Wyoming's Powell Research and Extension Center (PREC) (44 46' 35.03" N, $108^{\circ} 45^{\prime}$ $32.50^{\prime \prime}$ W, $1333 \mathrm{~m}$ above sea level) located near Powell, Wyoming. The soil at the site is Garland loam with $0.25 \mathrm{~m}^{3} \mathrm{~m}^{-3}$ field capacity (FC), $0.13 \mathrm{~m}^{3} \mathrm{~m}^{-3}$ permanent wilting point (PWP), and $0.43 \mathrm{~m}^{3} \mathrm{~m}^{-3}$ saturation point (SP) (NRCS Web Soil Survey; http://websoilsurvey.nrcs.usda.gov). The soil is categorized as deep, well-drained, and medium-textured with a surface slope of $0 \%$ to $1 \%$ and an average bulk density of $1.40 \mathrm{~g} \mathrm{~cm}^{-3}$. The total available water holding capacity of the $0.9 \mathrm{~m}$ soil profile is $108 \mathrm{~mm}$. The particle size distribution is $38 \%$ sand, $37 \%$ silt, and $24 \%$ clay, with $1.3 \%$ organic matter content in the topsoil. The research site is located in the arid region of intermountain northwest Wyoming. The long-term average annual precipitation in the region is $159 \mathrm{~mm}$, and the long-term average growing season (May to September) precipitation is $110 \mathrm{~mm}$, with significant interannual and growing season variations in both magnitude and timing.
In the intermountain region of Wyoming, the growing season is generally short, and the winters are long. The growing season usually starts in May and ends in mid to late September. The short growing season is due to a limited number of frost-free days in the year (approximately 118 days). Despite the limited growing season, the region provides an ideal environment for high-yielding and high-quality crops. The primary crops grown in the region include dry bean, barley, sugarbeet, and alfalfa, primarily under furrow irrigation with many growers switching to center-pivot irrigation. Because of the relatively low growing season precipitation and low relative humidity, disease incidence is minimal, cool winter temperatures suppress insect and disease cycles, and much of the acreage in the region is dedicated to producing certified seed, including dry beans. Consequently, information on effective irrigation management is essential for the crops grown for the commodity market as well as for the certified seed producers.

\section{EXPERIMENTAL DESIGN, IRRIGATION, and Management Practices}

Dry bean (Phaseolus vulgaris L.) cv. Othello (Pinto bean variety, Type III indeterminate growth habit) was planted on 3 June 2017, 6 June 2018, and 5 June 2019 at $0.56 \mathrm{~m}$ row spacing (east-west direction). In all three years, the experimental field was disc plowed and then roller harrowed before sowing. Each plot was 30 rows $(17 \mathrm{~m})$ wide and $40.5 \mathrm{~m}$ long. A buffer of 24 rows $(13 \mathrm{~m})$ wide and $40.5 \mathrm{~m}$ long was left between adjacent plots in each span of the lateral-move irrigation system to avoid overlap of the irrigation treatments. The population was 222,395 seeds ha ${ }^{-1}$, and the planting depth was 0.05 to $0.06 \mathrm{~m}$. All plots were fertilized uniformly with nitrogen and phosphorous (rate based on expected maximum yield) based on soil samples taken from different locations in the field before the start of each growing season. The residual soil nitrogen was credited and subtracted from the final nitrogen amount needed. Table 1 lists the agronomic practices, including planting, emergence, harvest dates and herbicide and fertilizer type amount and application dates for the three growing seasons.

Five irrigation treatments, i.e., full irrigation treatment (FIT), 75\% FIT, 50\% FIT, 25\% FIT, and 125\% FIT were evaluated for the three growing seasons using a randomized complete block design (RCBD) with three replications. In this study, FIT represents the irrigation setting at which the dry bean crop was irrigated when soil water depletion reached approximately $35 \%$ to $40 \%$ of the total available water. For the remaining treatments, the irrigation amounts were the named percentage of the FIT treatment. The $125 \%$ FIT treatment was added to assess the impact of over-irrigation on dry bean yield.

The experimental plots were irrigated using a nine-span GPS-guided linear-move sprinkler irrigation system with variable-rate irrigation (VRI) zone control capability (Valmont Industries, Valley, Neb.). All plots were located in the first three spans of the lateral-move system in 2017 and 2018 and in the fourth, fifth, and sixth spans in 2019. The irrigation system was fed from surface water supplies using a large-diameter hose attached to a pressurized mainline. The irrigation system consisted of a lateral pipeline $(0.2 \mathrm{~m}$ 
Table 1. Management practices and agronomic information for 2017, 2018, and 2019 dry bean growing seasons.

\begin{tabular}{|c|c|c|c|c|c|c|c|c|c|}
\hline \multirow[b]{2}{*}{ Year } & \multirow[b]{2}{*}{$\begin{array}{c}\text { Planting } \\
\text { Date }\end{array}$} & \multirow[b]{2}{*}{$\begin{array}{c}\text { Emergence } \\
\text { Date }\end{array}$} & \multirow[b]{2}{*}{$\begin{array}{c}\text { Harvest } \\
\text { Date }\end{array}$} & \multicolumn{3}{|c|}{ Herbicide, } & \multicolumn{3}{|c|}{ Fertilizer } \\
\hline & & & & $\begin{array}{c}\text { Application } \\
\text { Date }\end{array}$ & Name $^{[\mathrm{a}]}$ & $\begin{array}{l}\text { Amount } \\
\left(\mathrm{L} \mathrm{ha}^{-1}\right)\end{array}$ & $\begin{array}{c}\text { Application } \\
\text { Date }\end{array}$ & Type & $\begin{array}{l}\text { Amount } \\
\left(\mathrm{kg} \mathrm{ha}^{-1}\right)\end{array}$ \\
\hline 2017 & 3 June & 13 June & 8 Sept. & 25 May & $\begin{array}{c}\text { Sonalan } \\
\text { Eptam }\end{array}$ & $\begin{array}{l}2.3 \\
2.9 \\
\end{array}$ & 24 May & $\begin{array}{c}11-52-0 \\
46-0-0\end{array}$ & $\begin{array}{c}64 \\
105 \\
\end{array}$ \\
\hline 2018 & 6 June & 14 June & 10 Sept. & 1 June & $\begin{array}{l}\text { Sonalan } \\
\text { Outlook }\end{array}$ & $\begin{array}{c}2.3 \\
1\end{array}$ & 1 June & $\begin{array}{c}11-52-0 \\
46-0-0 \\
\text { Zinc sulfate }\end{array}$ & $\begin{array}{c}5 \\
87 \\
17 \\
\end{array}$ \\
\hline 2019 & 5 June & 14 June & 6 Sept. & 15 May & $\begin{array}{l}\text { Sonalan } \\
\text { Outlook }\end{array}$ & $\begin{array}{c}2.3 \\
1\end{array}$ & 29 April & $\begin{array}{c}11-52-0 \\
46-0-0 \\
\text { Zinc sulfate }\end{array}$ & $\begin{array}{c}5 \\
40 \\
6\end{array}$ \\
\hline
\end{tabular}

[a] Sonolan is ethanfluralin (N-ethyl-N-(2-methyl-2 propenyl)-2, 6-dinitro-4-(trifluoromethyl) benzenamine; Eptam is S-ethyl dipropylthiocarbamate (EPTC); and Outlook is dimethenamid-P: (S)-2chloro-N-[(1-methyl-2-methoxy)ethyl]-N-(2,4-dimethyl-thien-3-yl)-acetamide.

diameter) with 18 sprinkler drops spaced $2.3 \mathrm{~m}$ apart. The sprinkler system used rotator heads (R3000, Nelson Irrigation, Walla Walla, Wash.) with $69 \mathrm{kPa}$ pressure regulators installed $1.5 \mathrm{~m}$ above the ground. For each irrigation event, a prescription map was developed using the Valley VRI-iS prescription program (ver. 8.55) and then uploaded to the Valley AutoPilot Linear Control Panel (Valmont Industries, Valley, Neb.).

Irrigation scheduling for FIT was performed using a daily water balance based on the method presented in FAO-56 (Allen et al., 1998). Irrigation was applied when the projected water deficit in the root zone of the FIT treatment was equal to the minimum allowable depletion (MAD, 35\% to $40 \%$ of the available soil water). Irrigation was applied one or two times a week to meet the $\mathrm{ET}_{c}$ needs. The water deficit values calculated with this approach were adjusted based on measured soil moisture data for each soil moisture measurement date throughout the growing season. For each irrigation event, a maximum application of $31.8 \mathrm{~mm}$ and a minimum application of $12.7 \mathrm{~mm}$ were applied for FIT. The irrigation amount for the deficit irrigation treatments was reduced relative to FIT to achieve the target reduction and applied on the same day as FIT.

Although evaporation from the soil was not estimated in this study, small irrigation events $(<5 \mathrm{~mm})$ in the deficit irrigation treatments (especially $25 \%$ FIT) only wet the topsoil layers, and much of the water evaporated (soil evaporation and droplet evaporation), resulting in little soil water storage. In general, the irrigation application rate has a moderate effect on evaporation during the initial growth stage, when evaporation is relatively high and evaporation levels are more dependent on the potential evaporation rate. As the season progresses, the irrigation application rate becomes an important factor, and a larger irrigation application rate results in increasing evaporation, while the evaporation rate becomes constant for lower application amounts, which potentially affects the total cumulative evapotranspiration (Ji and Unger, 2001).

Volumetric soil moisture measurements were made once a week throughout each growing season in each plot at three depths $(0.3,0.6$, and $0.9 \mathrm{~m})$ using a neutron probe $(\mathrm{CPN}$ 503DR Elite Hydroprobe, Instrotek Inc., Grand Rapids, Mich.). The total soil water ( $\mathrm{mm}$ ) was calculated by multiplying the probe-measured volumetric soil moisture measurement with an equivalent depth of water in a soil layer. Before the start of the experiment, the neutron probe was calibrated against gravimetric soil moisture samples taken at the research site. The gravimetric soil moisture values were converted to volumetric soil moisture using bulk density that was measured using soil core samples taken at the same site at several depths. Neutron probe access tubes were installed in crop rows between two dry bean plants in each plot. Precautions were taken to avoid disturbing or damaging the plants during the access tube installation. The measured soil moisture was used to calculate soil moisture depletion in the root zone for irrigation management and to quantify $\mathrm{ET}_{c}$ for each treatment.

A uniform irrigation application of $12.7 \mathrm{~mm}$ was applied in all years at planting, and $19.1 \mathrm{~mm}$ in 2017 and $12.7 \mathrm{~mm}$ in 2018 and 2019 was applied at emergence. The purpose of these irrigations was to create a good seedbed and to encourage a full and even plant stand. The variable irrigation was initiated on 21 June 2017, 28 June 2018, and 24 June 2019. At the beginning of each growing season, the performance of the sprinkler irrigation system was verified using catch can tests. A total of 14, 13, and 12 irrigation events occurred in the 2017, 2018, and 2019 growing seasons, respectively (table 2). The greater irrigation application amounts in 2017 were due to drier and warmer conditions and greater atmospheric demand in comparison to 2018 and 2019 (table 3).

\section{CROP ET AND SOIL-WATER BALANCE}

Dry bean crop evapotranspiration $\left(\mathrm{ET}_{c}\right)$ was calculated for each plot using the soil water balance approach (ASCE, 2005):

$$
\mathrm{ET}_{c}=P+I+U-R O-D P \pm \Delta S
$$

where $P$ is precipitation ( $\mathrm{mm}), I$ is irrigation ( $\mathrm{mm}), U$ is upward water flux (assumed zero), $R O$ is runoff $(\mathrm{mm}), D P$ is deep percolation below the crop root zone $(\mathrm{mm})$, and $\Delta S$ is the change in soil water content. Runoff was calculated using the USDA-NRCS curve number method (USDA-SCS, 1985) and was determined for each plot. No visible runoff was observed from the plots during irrigation events or after precipitation. The curve number method accounts for initial abstraction losses and soil infiltration rate and relates the curve number to runoff (USDA-SCS, 1985). In this study, the soil at the experimental site belonged to USDA-NRCS hydrologic soil group B, which has curve numbers of 60,78 , and 90 for dry, average, and wet antecedent runoff conditions, respectively.

Deep percolation is defined as the downward movement of water from the bottom of the root zone to deeper depths. 
Table 2. Total irrigation applied $(\mathrm{mm})$ per event for each irrigation treatment for the 2017,2018 , and 2019 dry bean crop growing seasons $($ FIT $=$ full irrigation treatment $)$.

\begin{tabular}{|c|c|c|c|c|c|c|}
\hline & & $125 \%$ & & $75 \%$ & $50 \%$ & $25 \%$ \\
\hline Year & Date & FIT & FIT & FIT & FIT & FIT \\
\hline \multirow[t]{15}{*}{2017} & 7 June & 12.7 & 12.7 & 12.7 & 12.7 & 12.7 \\
\hline & 17 June & 19.1 & 19.1 & 19.1 & 19.1 & 19.1 \\
\hline & 21 June & 15.9 & 12.7 & 9.5 & 6.4 & 3.2 \\
\hline & 30 June & 23.8 & 19.1 & 14.3 & 9.5 & 4.8 \\
\hline & 3 July & 23.8 & 19.1 & 14.3 & 9.5 & 4.8 \\
\hline & 12 July & 31.8 & 25.4 & 19.1 & 12.7 & 6.4 \\
\hline & 15 July & 31.8 & 25.4 & 19.1 & 12.7 & 6.4 \\
\hline & 20 July & 31.8 & 25.4 & 19.1 & 12.7 & 6.4 \\
\hline & 25 July & 31.8 & 25.4 & 19.1 & 12.7 & 6.4 \\
\hline & 1 Aug. & 31.8 & 25.4 & 19.1 & 12.7 & 6.4 \\
\hline & 4 Aug. & 31.8 & 25.4 & 19.1 & 12.7 & 6.4 \\
\hline & 10 Aug. & 31.8 & 25.4 & 19.1 & 12.7 & 6.4 \\
\hline & 18 Aug. & 23.8 & 19.1 & 14.3 & 9.5 & 4.8 \\
\hline & 22 Aug. & 23.8 & 19.1 & 14.3 & 9.5 & 4.8 \\
\hline & Total & 365 & 298 & 232 & 165 & 98 \\
\hline \multirow[t]{14}{*}{2018} & 7 June & 12.7 & 12.7 & 12.7 & 12.7 & 12.7 \\
\hline & 12 June & 12.7 & 12.7 & 12.7 & 12.7 & 12.7 \\
\hline & 28 June & 15.9 & 12.7 & 9.5 & 6.4 & 3.2 \\
\hline & 4 July & 23.8 & 19.1 & 14.3 & 9.5 & 4.8 \\
\hline & 9 July & 23.8 & 19.1 & 14.3 & 9.5 & 4.8 \\
\hline & 19 July & 23.8 & 19.1 & 14.3 & 9.5 & 4.8 \\
\hline & 20 July & 23.8 & 19.1 & 14.3 & 9.5 & 4.8 \\
\hline & 26 July & 31.8 & 25.4 & 19.1 & 12.7 & 6.4 \\
\hline & 31 July & 31.8 & 25.4 & 19.1 & 12.7 & 6.4 \\
\hline & 7 Aug. & 31.8 & 25.4 & 19.1 & 12.7 & 6.4 \\
\hline & 12 Aug. & 31.8 & 25.4 & 19.1 & 12.7 & 6.4 \\
\hline & 17 Aug. & 31.8 & 25.4 & 19.1 & 12.7 & 6.4 \\
\hline & 22 Aug. & 23.8 & 19.1 & 14.3 & 9.5 & 4.8 \\
\hline & Total & 319 & 260 & 202 & 143 & 84 \\
\hline \multirow[t]{13}{*}{2019} & 8 June & 12.7 & 12.7 & 12.7 & 12.7 & 12.7 \\
\hline & 12 June & 12.7 & 12.7 & 12.7 & 12.7 & 12.7 \\
\hline & 24 June & 23.8 & 19.1 & 14.3 & 9.5 & 4.8 \\
\hline & 3 July & 31.8 & 25.4 & 19.1 & 12.7 & 6.4 \\
\hline & 8 July & 31.8 & 25.4 & 19.1 & 12.7 & 6.4 \\
\hline & 23 July & 31.8 & 25.4 & 19.1 & 12.7 & 6.4 \\
\hline & 26 July & 31.8 & 25.4 & 19.1 & 12.7 & 6.4 \\
\hline & 31 July & 15.9 & 12.7 & 9.5 & 6.4 & 3.2 \\
\hline & 5 Aug. & 23.8 & 19.1 & 14.3 & 9.5 & 4.8 \\
\hline & 8 Aug. & 31.8 & 25.4 & 19.1 & 12.7 & 6.4 \\
\hline & 18 Aug. & 23.8 & 19.1 & 14.3 & 9.5 & 4.8 \\
\hline & 22 Aug. & 23.8 & 19.1 & 14.3 & 9.5 & 4.8 \\
\hline & Total & 295 & 241 & 187 & 133 & 79 \\
\hline
\end{tabular}

Deep percolation occurs when the water applied is more than the soil can hold (i.e., field capacity). Deep percolation was calculated as follows using a daily water balance computer program (Bryant et al., 1992):

$$
D P_{i}=\max \left(P_{i}-R O_{i}+\frac{I_{i}}{f_{w}}-\mathrm{ET}_{c, i}-D_{r, i-1}, 0\right)
$$

where $D P_{i}$ is the deep percolation on day $i(\mathrm{~mm}), I_{i}$ is the irrigation depth on day $i(\mathrm{~mm}), P_{i}$ is the precipitation on day $i(\mathrm{~mm}), R O_{i}$ is the runoff depth from the soil surface on day $i(\mathrm{~mm}), f_{w}$ is the fraction of the soil wetted by irrigation, $\mathrm{ET}_{c, i}$ is the crop evapotranspiration on day $i(\mathrm{~mm})$, and $D_{r, i-1}$ is the cumulative depletion in the root zone at the end of day $i-1$ $(\mathrm{mm})$. The program calculated daily $\mathrm{ET}_{c}$ and the water balance in the crop root zone using a two-step approach from the grass-reference evapotranspiration $\left(\mathrm{ET}_{o}\right)$ and grass-reference crop coefficient $\left(K_{c}\right)$. $\mathrm{ET}_{o}$ is calculated based on the ASCE standardized reference evapotranspiration equation with a fixed canopy resistance (ASCE, 2005).

Weather data were obtained from the Wyoming Agricultural Climate Network (WACNet) weather station located at the experimental site (Sharma et al., 2018). Daily weather data included daily maximum and minimum air temperature $\left(T_{\max }\right.$ and $\left.T_{\min }\right)$, daily maximum and minimum relative humidity $\left(\mathrm{RH}_{\max }\right.$ and $\left.\mathrm{RH}_{\min }\right)$, wind speed at $3 \mathrm{~m}$ height $\left(u_{3}\right)$, incoming solar radiation $\left(R_{s}\right)$, and precipitation $(P)$.

\section{Yield Measurements and Statistical ANALysis}

At complete maturity, seed yield samples were collected by hand-harvesting an area of $3.3 \mathrm{~m}^{2}(3 \mathrm{~m} \times 1.1 \mathrm{~m}$ in the center two rows) at three locations in each plot and threshing to quantify the seed yield per hectare. The yield was adjusted to $14 \%$ moisture content after threshing and then used in the crop water productivity and $K_{y}$ analysis. In addition, two plant samples were collected at the same locations to quantify the yield components, i.e., pods per plant, seeds per pod, and 100-seed weight. Analysis of variance (ANOVA) was conducted using IBM-SPSS Statistics. Tukey's honest significant difference (HSD) test at a 95\% confidence interval was used to identify significant differences between treatments. In addition to ANOVA, coefficients of determination $\left(\mathrm{R}^{2}\right)$ and standard deviations were used to determine the goodness-of-fit of the developed relationships.

\section{YIELD RESPONSE FACTOR}

To evaluate the crop response to water deficit conditions relative to FIT, the yield response factor $\left(K_{y}\right)$ was quantified.

Table 3. Monthly weather conditions for the 2017, 2018, and 2019 growing seasons and long-term (2010 to 2019) averages for growing seasons (June to August) at Powell Research and Extension Center (PREC), Powell, Wyoming. ${ }^{[a]}$

\begin{tabular}{|c|c|c|c|c|c|c|c|c|c|c|c|c|c|c|}
\hline Year & Month & $\begin{array}{l}T_{\max } \\
\left({ }^{\circ} \mathrm{C}\right)\end{array}$ & $\begin{array}{l}T_{\min } \\
\left({ }^{\circ} \mathrm{C}\right)\end{array}$ & $\begin{array}{l}T_{\text {avg }} \\
\left({ }^{\circ} \mathrm{C}\right)\end{array}$ & $\begin{array}{c}\mathrm{RH}_{\max } \\
(\%)\end{array}$ & $\begin{array}{c}\mathrm{RH}_{\text {min }} \\
(\%)\end{array}$ & $\begin{array}{c}\mathrm{RH}_{\text {avg }} \\
(\%)\end{array}$ & $\begin{array}{c}u_{3} \\
\left(\mathrm{~m} \mathrm{~s}^{-1}\right)\end{array}$ & $\begin{array}{c}R_{S} \\
\left(\mathrm{~W} \mathrm{~m}^{-2}\right)\end{array}$ & $\begin{array}{c}P \\
(\mathrm{~mm})\end{array}$ & $\begin{array}{c}T_{\max }>30 \\
\left({ }^{\circ} \mathrm{C}\right)\end{array}$ & $\begin{array}{l}\text { GDD } \\
\left({ }^{\circ} \mathrm{C}\right)\end{array}$ & $\begin{array}{l}\mathrm{VPD} \\
(\mathrm{kPa})\end{array}$ & $\begin{array}{c}\mathrm{ET}_{o} \\
(\mathrm{~mm})\end{array}$ \\
\hline \multirow[t]{3}{*}{2017} & June & 26.7 & 10.2 & 18.5 & 79.3 & 19.4 & 49.4 & 1.9 & 296.3 & 22.6 & 8.0 & 397.3 & 1.6 & 165.4 \\
\hline & July & 32.6 & 13.2 & 22.9 & 78.7 & 15.6 & 47.1 & 1.4 & 292.7 & 11.2 & 28.0 & 507.0 & 2.3 & 178.5 \\
\hline & August & 29.0 & 11.3 & 20.2 & 73.9 & 19.0 & 46.4 & 1.1 & 240.0 & 3.1 & 14.0 & 456.0 & 1.9 & 130.6 \\
\hline \multirow[t]{3}{*}{2018} & June & 25.5 & 9.8 & 17.7 & 87.0 & 26.4 & 56.7 & 1.6 & 274.5 & 48.8 & 5.0 & 376.7 & 1.4 & 147.6 \\
\hline & July & 30.6 & 12.9 & 21.8 & 78.5 & 19.5 & 49.0 & 1.2 & 287.0 & 4.8 & 15.0 & 492.6 & 2.0 & 160.5 \\
\hline & August & 28.1 & 10.8 & 19.4 & 80.6 & 22.5 & 51.6 & 1.2 & 233.4 & 22.9 & 14.0 & 426.3 & 1.8 & 126.3 \\
\hline \multirow[t]{3}{*}{2019} & June & 24.3 & 8.9 & 16.6 & 85.5 & 24.5 & 55.0 & 1.4 & 265.4 & 32.5 & 3.0 & 351.2 & 1.3 & 135.9 \\
\hline & July & 29.2 & 12.8 & 21.0 & 84.0 & 23.5 & 53.8 & 1.5 & 275.5 & 44.2 & 13.0 & 481.5 & 1.7 & 160.0 \\
\hline & August & 29.3 & 11.9 & 20.6 & 80.4 & 20.5 & 50.5 & 1.5 & 252.0 & 13.0 & 15.0 & 469.7 & 1.8 & 146.4 \\
\hline \multirow{3}{*}{$\begin{array}{l}\text { Long-Term } \\
(2010-2019)\end{array}$} & June & 27 & 10 & 18.4 & 79.7 & 20.8 & 50.3 & 1.9 & 301.7 & 19.1 & 7.0 & 376.2 & 1.6 & 158.8 \\
\hline & July & 31 & 13 & 22.3 & 78 & 17.3 & 47.6 & 1.5 & 297.8 & 9.5 & 20.8 & 496.9 & 2.1 & 176.9 \\
\hline & August & 30 & 12 & 20.5 & 77.8 & 19.3 & 48.5 & 1.4 & 247.4 & 10.7 & 16.5 & 461.3 & 1.9 & 143.7 \\
\hline
\end{tabular}

[a] $T_{\max }, T_{\min }$, and $T_{\text {avg }}=$ maximum, minimum, and average air temperature; $\mathrm{RH}_{\max }, \mathrm{RH}_{\min }$, and $\mathrm{RH}_{\text {avg }}=$ maximum, minimum, and average relative humidity; $u_{3}=$ wind speed at $3 \mathrm{~m}$ height, $R_{s}=$ incoming shortwave radiation, $P=$ precipitation; $T_{\max }>30=$ number of days when $T_{\max }$ exceeds $30^{\circ} \mathrm{C}$; GDD $=$ growing degree days with $5^{\circ} \mathrm{C}$ base temperature (Rai et al., 2020); VPD $=$ vapor pressure deficit, and $\mathrm{ET}_{o}=$ grass-reference evapotranspiration. 
Defined as the relative decrease in yield to the relative deficit in $\mathrm{ET}_{c}, K_{y}$ was introduced by Doorenbos and Kassam (1979) and is extensively used in irrigation research (Irmak, 2014; Kuscu et al., 2013; Singh et al., 2010; Shrestha et al., 2010; Kirda et al., 1999). The $K_{y}$ value is used to differentiate the drought tolerance of crops, varieties, and management practices and is expressed as:

$$
K_{y}=\frac{\left(1-Y_{c} / Y_{m}\right)}{\left(1-\mathrm{ET}_{c} / \mathrm{ET}_{m}\right)}
$$

where $Y_{c}$ is the actual seed yield $\left(\mathrm{kg} \mathrm{ha}^{-1}\right), Y_{m}$ is the maximum seed yield $\left(\mathrm{kg} \mathrm{ha}^{-1}\right), \mathrm{ET}_{c}$ is the actual crop evapotranspiration $(\mathrm{mm})$, and $\mathrm{ET}_{m}$ is the maximum crop evapotranspiration $(\mathrm{mm}),\left(1-Y_{c} / Y_{m}\right)$ is the reduction in relative yield, and $\left(1-\mathrm{ET}_{c} / \mathrm{ET}_{m}\right)$ is the reduction in relative crop $\mathrm{ET}_{c}$. In addition to the irrigation amount, both components of the $K_{y}$ relationship are affected by the method of water application (sprinkler vs. furrow vs. drip), climate variability, crop variety, fertilizer application, salinity, pest/weed/disease pressures, as well as local management conditions. Therefore, development of local values of $K_{y}$ for different crops is critical to evaluate the relationship between crop yield and water use (Doorenbos and Kassam, 1979).

\section{RESULTS AND DISCUSSIONS}

\section{WEATHER CONDITIONS IN 2017, 2018, AND 2019}

Differences in dry bean seed yield and yield components could be attributed to the difference in environmental conditions, such as the magnitude and distribution of rainfall and air temperature during the growing season. A summary of monthly average weather parameters is presented in table 3 . In addition, monthly cumulative growing degree days (GDD) and the number of days with $T_{\max }>30^{\circ} \mathrm{C}$ for the 2017, 2018, and 2019 growing seasons are included to illustrate the differences in weather conditions among the three years. The companion article (Rai et al., 2020) provides detailed descriptions of the differences in climate variables among the three growing seasons. Some of the key differences are provided here. The 2017 growing season was, in most cases, similar to the long-term average climate, and the 2018 and 2019 growing seasons were characterized by higher precipitation and lower temperatures than the longterm climate. Total growing season precipitation $(P)$ of 37 , 77 , and $90 \mathrm{~mm}$ was observed from planting to harvest in 2017, 2018, and 2019, respectively. The coolest growing season occurred in 2019, with seasonal average temperatures $\left(T_{\text {avg }}\right)$ that were $1.1^{\circ} \mathrm{C}$ and $0.2^{\circ} \mathrm{C}$ lower than the 2017 and 2018 growing seasons, respectively. Even though there were differences in the planting and harvesting dates among three years, for the sake of simplicity and comparison, we compared GDD from 1 June to 10 September. Overall, because of the warmer climate in 2017, the cumulative GDD was higher for 2017 compared to 2018 and 2019, with total cumulative GDD of $1502^{\circ} \mathrm{C}, 1424^{\circ} \mathrm{C}$, and $1441^{\circ} \mathrm{C}$, respectively.

\section{EFFECTS OF IRRIGATION TREATMENTS ON SOIL WATER BALANCE COMPONENTS}

The effects of the different irrigation treatments on dry bean crop evapotranspiration $\left(\mathrm{ET}_{c}\right)$ and other water balance components, i.e., change in soil moisture status $(\Delta S)$ from beginning to end of the growing season, runoff $(R O)$, and deep percolation $(D P)$, are shown in table 4 . The $R O$ and $D P$ were minimal for all irrigation treatments in all years. The maximum seasonal $D P$ values of 29 and $20 \mathrm{~mm}$ were observed in the $125 \%$ FIT and FIT plots in July 2019, corresponding to precipitation events from 26 June to 10 July (cumulative precipitation of $40 \mathrm{~mm}$ ), along with one irrigation event of $25.4 \mathrm{~mm}$. In 2018, precipitation events from 16 to 24 June (cumulative precipitation of $46 \mathrm{~mm}$ ) also resulted in $D P$ of $11.8 \mathrm{~mm}$ in all treatments early in the growing season. This happened before the start of variable-rate irrigation, when the soil moisture was similar under all irrigation treatments.

Table 4. Dry bean seasonal water balance components, yield, and yield components during the 2017, 2018 , and 2019 growing seasons. ${ }^{\text {[a] }}$

\begin{tabular}{|c|c|c|c|c|c|c|c|c|c|c|c|}
\hline Year & Treatment & $\begin{array}{c}P \\
(\mathrm{~mm})\end{array}$ & $\begin{array}{c}I \\
(\mathrm{~mm})\end{array}$ & $\begin{array}{c}R O \\
(\mathrm{~mm})\end{array}$ & $\begin{array}{c}D P \\
(\mathrm{~mm})\end{array}$ & $\begin{array}{c}\Delta S \\
(\mathrm{~mm})\end{array}$ & $\begin{array}{c}\mathrm{ET}_{c} \\
(\mathrm{~mm})\end{array}$ & $\begin{array}{c}\text { Seed } \\
\text { Yield } \\
\left(\mathrm{kg} \mathrm{ha}^{-1}\right)\end{array}$ & $\begin{array}{c}\text { Pods } \\
\text { per } \\
\text { Plant }\end{array}$ & $\begin{array}{c}\text { Seeds } \\
\text { per } \\
\text { Pod }\end{array}$ & $\begin{array}{c}\text { 100-Seed } \\
\text { Weight } \\
(\mathrm{g})\end{array}$ \\
\hline \multirow[t]{5}{*}{2017} & $25 \%$ FIT & 37 & 96 & 0 & 0 & -26 & $187 \mathrm{a}$ & $264 \mathrm{a}$ & $7 \mathrm{a}$ & $2.1 \mathrm{a}$ & $25 \mathrm{a}$ \\
\hline & $50 \%$ FIT & 37 & 160 & 0 & 0 & -18 & $258 \mathrm{~b}$ & $1086 \mathrm{ab}$ & $13 \mathrm{~b}$ & $2.6 \mathrm{ab}$ & $27 \mathrm{a}$ \\
\hline & $75 \%$ FIT & 37 & 225 & 0 & 0 & -17 & $321 \mathrm{c}$ & 2304 bc & $14 \mathrm{~b}$ & $2.9 \mathrm{ab}$ & $34 \mathrm{~b}$ \\
\hline & FIT & 37 & 289 & 0 & 0 & -14 & $369 \mathrm{~d}$ & $3630 \mathrm{c}$ & $17 \mathrm{~b}$ & $3 \mathrm{~b}$ & $37 b$ \\
\hline & $125 \%$ FIT & 37 & 375 & 0 & 10.5 & 1 & $438 \mathrm{e}$ & $3306 \mathrm{c}$ & $17 \mathrm{~b}$ & $2.9 \mathrm{~b}$ & $36 \mathrm{~b}$ \\
\hline \multirow[t]{5}{*}{2018} & $25 \%$ FIT & 74 & 84 & 0 & 11.8 & -27 & $190 \mathrm{a}$ & $278 \mathrm{a}$ & $4 \mathrm{a}$ & $2.9 \mathrm{a}$ & $28 \mathrm{a}$ \\
\hline & $50 \%$ FIT & 74 & 143 & 0 & 11.8 & -21 & $243 \mathrm{~b}$ & $1095 \mathrm{~b}$ & $9 \mathrm{ab}$ & $2.6 \mathrm{ab}$ & $33 \mathrm{~b}$ \\
\hline & $75 \%$ FIT & 74 & 202 & 0 & 11.8 & -13 & 293 c & $2311 \mathrm{c}$ & $13 \mathrm{bc}$ & $3.3 \mathrm{abc}$ & $37 \mathrm{c}$ \\
\hline & FIT & 74 & 261 & 0.3 & 11.8 & -6.6 & $348 \mathrm{~d}$ & $3822 d$ & $17 \mathrm{c}$ & $3.6 \mathrm{bc}$ & $40 \mathrm{c}$ \\
\hline & $125 \%$ FIT & 74 & 330 & 1.5 & 11.8 & 0.2 & $409 \mathrm{e}$ & $3826 \mathrm{~d}$ & $16 \mathrm{bc}$ & $3.8 \mathrm{c}$ & $40 \mathrm{c}$ \\
\hline \multirow[t]{5}{*}{2019} & $25 \%$ FIT & 89 & 79 & 0 & 0 & -3 & $217 \mathrm{a}$ & $1436 \mathrm{a}$ & $10 \mathrm{a}$ & $3.4 \mathrm{a}$ & $30 \mathrm{a}$ \\
\hline & $50 \%$ FIT & 89 & 133 & 0 & 0 & -14 & $278 \mathrm{a}$ & $2524 \mathrm{~b}$ & $12 a b$ & $3.9 \mathrm{ab}$ & $33 \mathrm{ab}$ \\
\hline & $75 \%$ FIT & 89 & 187 & 0 & 0 & 0.3 & $336 \mathrm{~b}$ & 3192 bc & $14 a b c$ & $4 \mathrm{~b}$ & $37 \mathrm{bc}$ \\
\hline & FIT & 89 & 241 & 1 & 20 & 2.1 & $365 \mathrm{bc}$ & $3665 \mathrm{c}$ & $17 \mathrm{c}$ & $4.3 \mathrm{~b}$ & $38 \mathrm{c}$ \\
\hline & $125 \%$ FIT & 89 & 297 & 3 & 29 & 8.1 & $398 \mathrm{c}$ & $3599 \mathrm{c}$ & $16 \mathrm{bc}$ & $4 \mathrm{~b}$ & $38 \mathrm{c}$ \\
\hline Average & $25 \%$ FIT & 67 & 86 & 0 & 4 & -19 & 198 & 659 & 7 & 3 & 28 \\
\hline \multirow{4}{*}{$(2017-2019)$} & $50 \%$ FIT & 67 & 145 & 0 & 4 & -18 & 260 & 1568 & 11 & 3 & 31 \\
\hline & $75 \%$ FIT & 67 & 205 & 0 & 4 & -10 & 317 & 2602 & 14 & 3 & 36 \\
\hline & FIT & 67 & 264 & 0 & 11 & -6 & 361 & 3706 & 17 & 4 & 38 \\
\hline & $125 \%$ FIT & 67 & 334 & 2 & 17 & 3 & 415 & 3577 & 16 & 4 & 38 \\
\hline
\end{tabular}

[a] $P=$ precipitation, $I=$ irrigation, $R O=$ runoff, $D P=$ deep percolation, $\Delta S=$ changes in root-zone soil moisture, and ET $=$ crop evapotranspiration. 
The seasonal distribution of average measured and water balance simulated (FAO-56 two-step dual crop coefficient model) total available soil moisture in the active root zone for the different irrigation treatments for the three growing seasons is presented in figure 1 . The soil moisture measurements were initiated on 21 June 2017, 27 June 2018, and 2 July 2019. Uniform irrigation was applied to all treatments at planting and emergence before the initiation of soil moisture measurement to ensure that the initial soil moisture was similar for each plot. In all growing seasons, soil moisture measurements were taken two to three days after each irrigation event. As expected, the availability of soil moisture in the soil profile was affected by the amount of irrigation applied during the growing season, with considerable differences observed among irrigation treatments in all years. The dynamics of soil moisture showed the typical pattern, with soil moisture decreasing with the decrease in irrigation level. However, in the 2018 growing season, soil moisture was higher for FIT than for $125 \%$ FIT due to higher stored soil moisture at the $0.9 \mathrm{~m}$ soil depth in one of the replications. This may have been a result of the higher clay percentage in the soil at this depth (data not shown). Variation in soil texture at deeper depths is a characteristic of Garland loam soil. In all years, a gradual decrease in soil moisture was observed from the mid-development growth stage to physiological maturity for the deficit irrigation treatments. The volumetric soil water content of the deficit irrigation treatments, especially $25 \%$ FIT and 50\% FIT, remained below MAD after the mid-development growth stage, indicating that the crop was under severe water stress, which had a significant impact on dry bean yield.
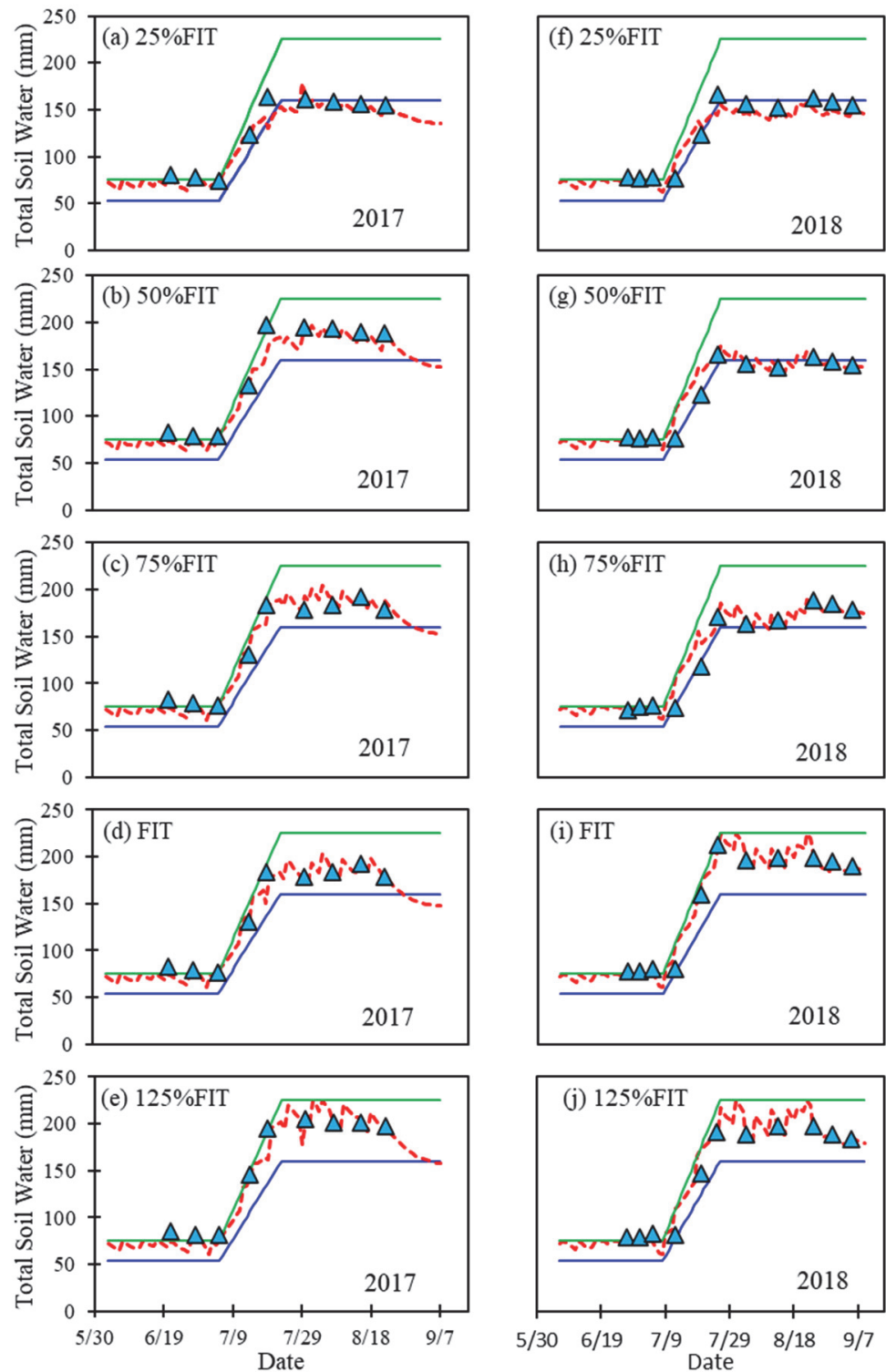
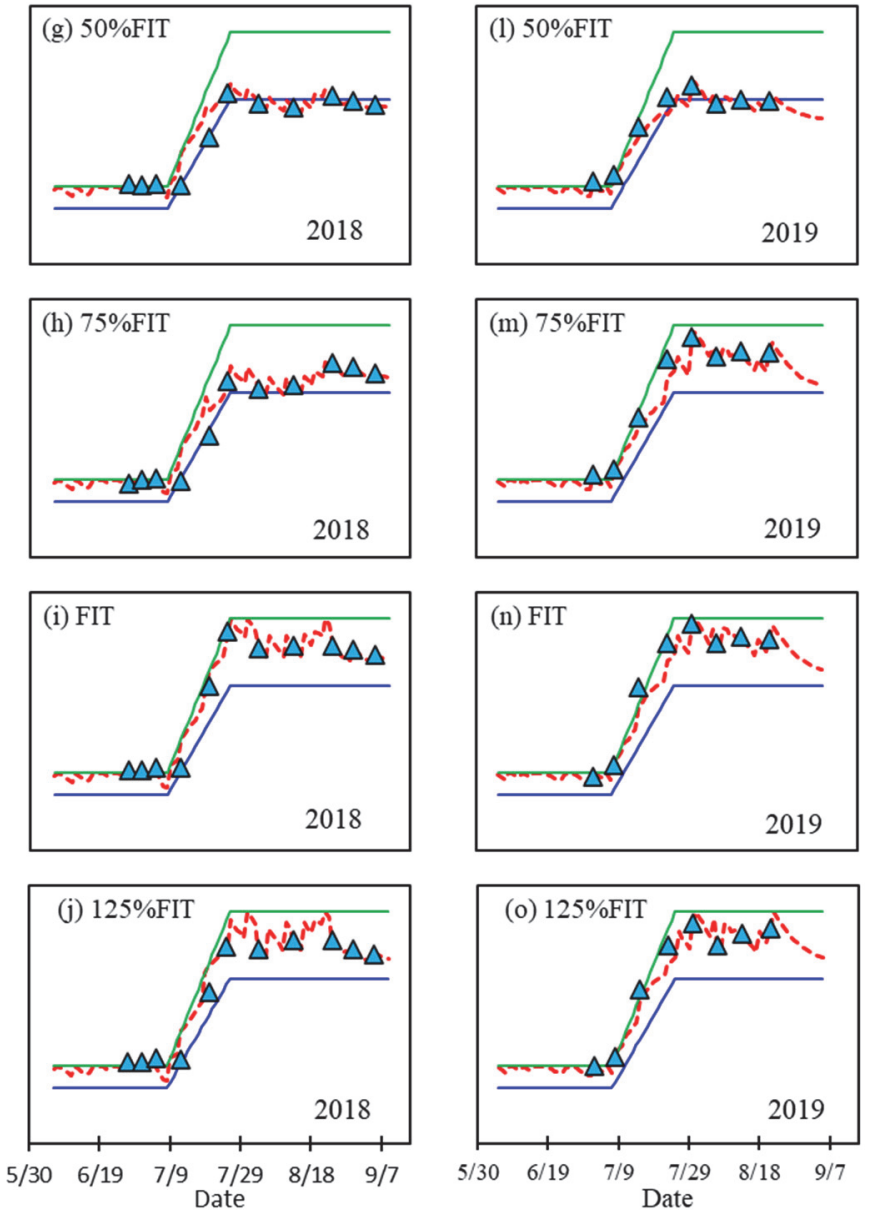

$\Delta \quad$ Measured TSW FC

Figure 1. Dry bean measured (solid triangles) and water balance simulated (dotted red lines) average total soil water (TSW, mm) for 25\% FIT, $50 \%$ FIT, 75\% FIT, FIT, and $125 \%$ FIT in the active root zone for the 2017 (left column), 2018 (middle column), and 2019 (right column) growing seasons (FIT $=$ full irrigation treatment, MAD = manageable allowable depletion, and FC = field capacity). 
No major differences in soil moisture content were observed between FIT and 125\% FIT in all growing seasons, with soil moisture consistently between field capacity and MAD. In FIT and $125 \%$ FIT, soil moisture fluctuation was observed in the top $0.3 \mathrm{~m}$ of the soil profile, but soil moisture varied little at the 0.6 and $0.9 \mathrm{~m}$ depths. However, for the deficit irrigation treatments, some soil moisture depletion was observed in the deeper layers. For example, for all deficit irrigation treatments, the soil moisture content at the $0.9 \mathrm{~m}$ soil depth decreased below $0.15 \mathrm{~mm} \mathrm{~mm}^{-1}$ near the end of the growing season. In general, dry bean is a shallowrooted crop, with most of the roots concentrated in the top $0.3 \mathrm{~m}$ of the soil profile under optimal moisture conditions. When water is not limiting, the roots show hydrotropism and concentrate in areas of higher water potential (FIT and 125\% FIT). With water stress, the roots show xerotropism and move deeper into the soil (25\% FIT, 50\% FIT, and $75 \%$ FIT). Similar results were observed by Al-Kaisi et al. (1999) for dry bean; they reported no water extraction below $0.3 \mathrm{~m}$ soil depth under full and excess irrigation treatments and soil water extraction from $0.6 \mathrm{~m}$ for $0.33 \mathrm{ET}_{c}$ and $0.67 \mathrm{ET}_{c}$ treatments. Muñoz-Perea et al. (2007) evaluated the water potential at soil depths of $0.23,0.46$, and $0.92 \mathrm{~m}$ for two dry bean landraces and four cultivars under intermittent drought stress and observed most of the water extraction from the soil profile at $0.23 \mathrm{~m}$, followed by $0.46 \mathrm{~m}$, and no significant differences in water potential at $0.92 \mathrm{~m}$.

The water balance calculated crop evapotranspiration $\left(\mathrm{ET}_{c}\right)$ was significantly different among the irrigation treatments, except in 2019 (table 4), with $25 \% \mathrm{FIT} \mathrm{ET}_{c}$ varying between $50 \%$ and $60 \%$ of FIT ET E $_{c}$. Large differences among treatments were primarily due to differences in total water application (precipitation plus irrigation) because the differences in other water balance components, such as $R O, D P$, and $\Delta S$, were relatively small. In all growing seasons, deficitirrigated dry bean suffered water stress during the vegetation phase, which created a difference in seasonal $\mathrm{ET}_{c}$ among treatments, with minimum $\mathrm{ET}_{c}$ observed for $25 \%$ FIT, followed by $50 \%$ FIT, $75 \%$ FIT, FIT, and $125 \%$ FIT. The difference in $\mathrm{ET}_{c}$ began during V3 (3rd trifoliate) in 2017 $\left(\mathrm{GDD}=428^{\circ} \mathrm{C}\right)$, compared to $2018\left(624^{\circ} \mathrm{C}\right)$ and 2019 $\left(632^{\circ} \mathrm{C}\right)$, when the major difference in $\mathrm{ET}_{c}$ started to appear during V4 and V5 (branching and rapid vegetation growth stages) (fig. 2).

Although no significant effects of seasonal irrigation and total water supply on total growing season $\mathrm{ET}_{c}$ were observed among years in this study, significant variation in $\mathrm{ET}_{c}$ was observed during different growth stages among years as a function of the variability in precipitation, irrigation amount and timing, and variation in other climate variables among years. Approximately $41 \%, 47 \%$, and $53 \%$ of total $\mathrm{ET}_{c}$ occurred from planting to flowering in the non-stressed treatments for a growing period of approximately 40 to 45 days, while $59 \%, 53 \%$, and $47 \%$ of total $\mathrm{ET}_{c}$ occurred during flowering to maturation (R5 to harvest) in 2017, 2018, and 2019, respectively. Higher $\mathrm{ET}_{c}$ early in the vegetation growth stages in 2019 was characterized by higher precipitation during the early part of the growing season. Averaged across all years, the daily $\mathrm{ET}_{c}$ for FIT varied by

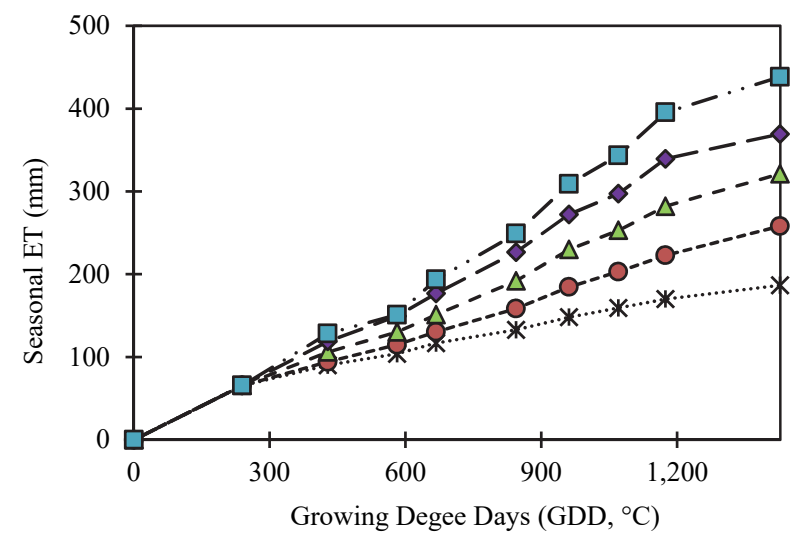

(a) 2017

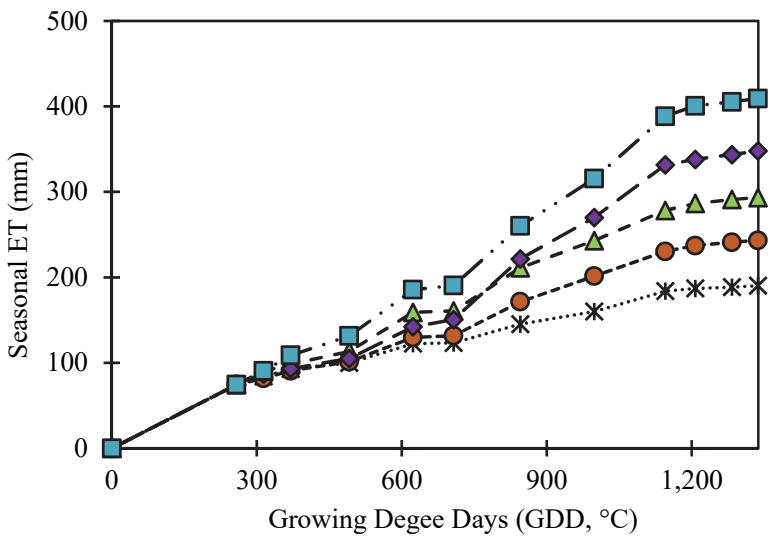

(b) 2018

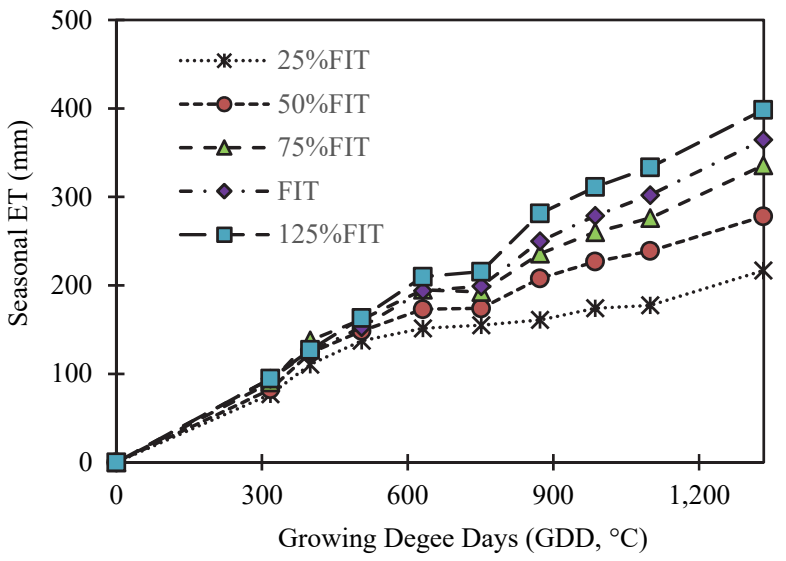

(c) 2019

Figure 2. Cumulative growing season crop evapotranspiration $\left(\mathbf{E T}_{c}\right)$ for different irrigation treatments of dry bean during the (a) 2017 , (b) 2018, and (c) 2019 growing seasons at the Powell Research and Extension Center, Powell, Wyoming.

$3.58 \mathrm{~mm}$ in June, by $3.72 \mathrm{~mm}$ in July, and by $3.86 \mathrm{~mm}$ in August. Al-Kaisi et al. (1999) observed a comparable $\mathrm{ET}_{c}$ range for dry bean in response to incremental irrigation gradients in southwestern Colorado. They reported an average range of 73.6 to $553.7 \mathrm{~mm}$ from 0.0 ET to 1.33 ET (increment of 0.33 ET) under drip irrigation. Similar dry bean $\mathrm{ET}_{c}$ values were reported by Yonts et al. (2018) in western Nebraska, with seasonal dry bean $\mathrm{ET}_{c}$ ranging between 362 and $432 \mathrm{~mm}$ from 2010 to 2015 for fully irrigated dry bean. 


\section{DRY BEAN YIELD RESPONSE TO IRRIGATION (IRrigation Water Production Functions)}

The irrigation amount significantly influenced the dry bean yield and yield components (table 4). As expected, the average dry bean yield showed a decreasing trend with a reduction in irrigation water applied. A detailed description of the variation in dry bean yield and its relationship with dry bean eco-physiological parameters, i.e., leaf area index (LAI), normalized difference vegetation index (NDVI), and plant height $(h)$, was presented by Rai et al. (2020).

The relationship between dry bean yield and cumulative irrigation water applied, i.e., irrigation production function (IWPF), is characterized by a two-segment relationship. As shown in figure $3 \mathrm{a}$, the relationship between dry bean yield and seasonal irrigation was more or less linear up to FIT. Thereafter, irrigation became excessive, resulting in no significant increase in yield (no return). A similar non-increasing trend of yield when the water consumption was above a certain threshold was observed by Kang et al. (2002) for wheat, maize, and cotton in northwest China. Similar to Spurgeon and Yonts (2013), it was observed that the timing of irrigation in relationship to the plant growth stage, especially at bloom and pod set, may be more critical than simply applying larger amounts of irrigation water.

Elimination of $125 \%$ FIT from the IWPF analysis resulted in a linear relationship for the 2017 and 2018 growing seasons, with $\mathrm{R}^{2}$ values exceeding 0.98. In 2019, the relationship was curvilinear and was a better fit with a seconddegree polynomial $\left(\mathrm{R}^{2}=0.99\right)$ (fig. $3 \mathrm{~b}$ ). This may be due to variation in seasonal $P$ among the three growing seasons. Total growing season $P$ of 37,77, and $90 \mathrm{~mm}$ was observed from planting to harvest in 2017, 2018, and 2019, respectively. This indicates that during dry years, crop water

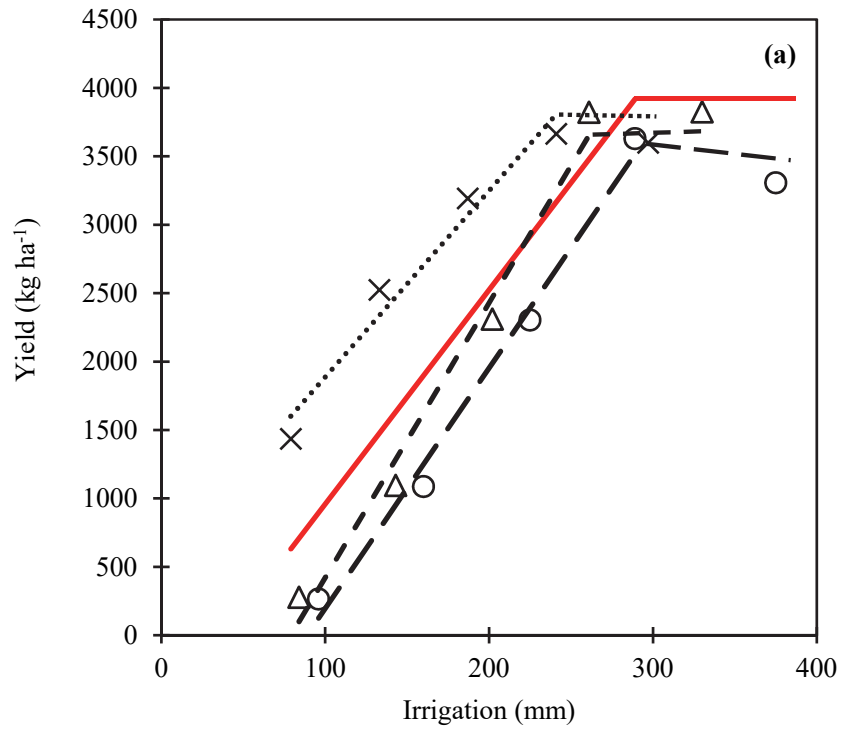

productivity was high, with minimal percolation and runoff losses, and it is possible that potential $\mathrm{ET}_{c}$ was not reached by FIT. Thus, the yield versus irrigation curve resulted in a linear relationship in 2017 and 2018. The curvilinearity and downward curvature for IWPF in 2019 was due to the fact that more of the irrigation water went to $D P$ and $\Delta S$ at a high level of irrigation, indicating a diminishing return for irrigation applications approaching full irrigation. In addition, uncertainty in dry bean yield decreased as the amount of irrigation increased. These results indicated that higher income risk was associated with deficit irrigation than with full irrigation.

The linear IWPF results indicated that dry bean yield increased at rates of 17.4 and $20.1 \mathrm{~kg} \mathrm{ha}^{-1} \mathrm{~mm}^{-1}$ of irrigation water applied in 2017 and 2018, respectively. The pooled linear IWPF indicated that, under the typical climate conditions of the Big Horn basin in Wyoming, dry bean yield increased at a rate of $15.7 \mathrm{~kg} \mathrm{ha}^{-1} \mathrm{~mm}^{-1}$. Similar IWPF results were reported by Miller and Burke (1983) in south-central Washington and by Yonts et al. (2018) in western Nebraska. They reported that the average response of dry bean yield to applied irrigation ranged from 16.2 to $17.4 \mathrm{~kg} \mathrm{ha}^{-1} \mathrm{~mm}^{-1}$ in south-central Washington and from 5 to $22 \mathrm{~kg} \mathrm{ha}^{-1} \mathrm{~mm}^{-1}$ in western Nebraska. The difference between the dry bean yield response to irrigation observed in this study and the published values is due to differences in the irrigation systems, variation in climate variables (e.g., distribution of precipitation), and the experimental design. For example, Miller and Burke (1983) used a solid-set sprinkler system (application efficiency of $60 \%$ to $70 \%$ ) on sandy soil compared to Yonts et al. (2018) and this study, in which dry bean crops were irrigated using center-pivot and lateral-move systems on sandy loam and loam, respectively.
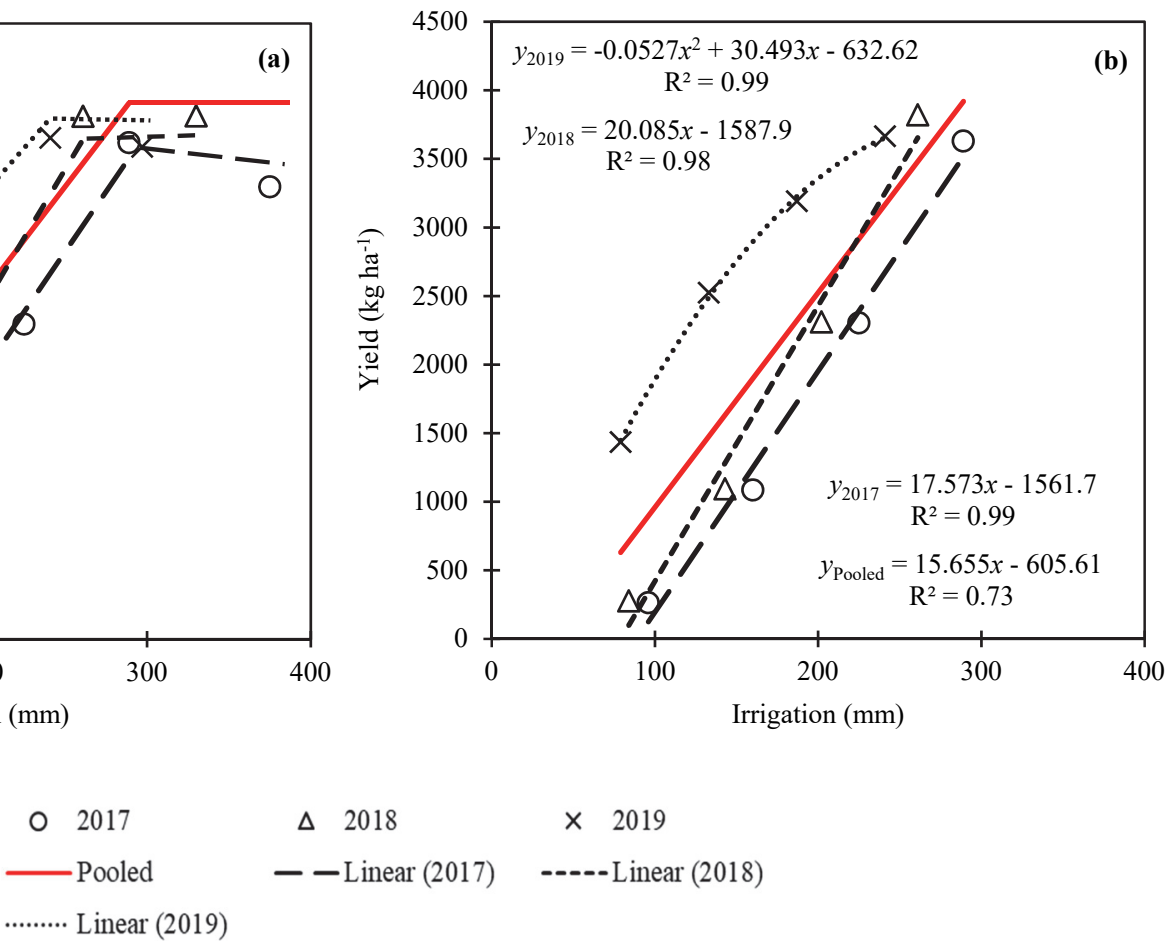

Figure 3. Dry bean yield response to irrigation, i.e., irrigation production function (IWPF): (a) with excess water treatment and (b) without excess water treatment for $2017,2018,2019$, and pooled data. 
The year effect on irrigation response can be seen from the individual-year regression models. For example, figure 3 shows considerable variation in IWPF for the three cropping seasons. This was primarily due to the amount and distribution of in-season rainfall, variations in water stored in the soil profile at crop emergence, changes in evaporative demand, different management practices (irrigation, nutrients, weed and pest control), and sensitivity of the dry bean crop to water deficit at different growth stages. For example, the highest dry bean yields in 2017 (3630 $\left.\mathrm{kg} \mathrm{ha}^{-1}\right), 2018$ $\left(3825 \mathrm{~kg} \mathrm{ha}^{-1}\right)$, and $2019\left(3665 \mathrm{~kg} \mathrm{ha}^{-1}\right)$ were associated with seasonal irrigation amounts of 290,330 , and $240 \mathrm{~mm}$, respectively.

This study indicated that under the typical climate conditions of the Big Horn basin, the optimal cumulative seasonal irrigation of approximately $264 \mathrm{~mm}$ resulted in maximum yield. It is important to note that, because of interaction among the aforementioned factors, it is difficult to develop irrigation strategies that maximize yield for indeterminate crops such as dry bean, especially with deficit irrigation. Excessive irrigation at the wrong time can result in excessive vegetation growth and blossom set without setting and filling pods. The significant variability of IWPF observed in this study also illustrates the importance of developing the relationship between crop yield and crop water use (CWPF), which is more stable than IWPF (Payero et al., 2006; Irmak, 2014, Trout and DeJonge, 2017).

\section{DRY BEAN YiELd RESPONSE TO CROP ET (Crop Water Production Functions)}

The response of dry bean yield to $\mathrm{ET}_{c}$, i.e., crop water production function (CWPF), for each year and pooled data are presented in figure 4. Irrigation and precipitation above the amount necessary to meet the crop water needs resulted in greater vegetation growth (Rai et al., 2020) and thus greater $\mathrm{ET}_{c}$, without providing more yield. In fact, in two of the years (2017 and 2019), yields were reduced by irrigation in excess of the amount required for FIT. Therefore, the excess water treatment $(125 \%$ FIT) was not included in the CWPF analysis. For all three years, dry bean yield and $\mathrm{ET}_{c}$ had a strong linear relationship, with $\mathrm{R}^{2}$ values ranging from 0.97 in 2017 to 0.99 in 2019, and the three-year pooled data had an $\mathrm{R}^{2}$ of 0.92 .

In general, the CWPF represents the limits for water-limiting crop productivity or seasonal transpiration efficiency (slope) and threshold $\mathrm{ET}_{c}(x$-intercept or offset) (Sinclair et al., 1984). The pooled regression slope, representing the average seasonal water-limiting crop productivity, was estimated as $18.9 \mathrm{~kg} \mathrm{ha}^{-1} \mathrm{~mm}^{-1}$ of $\mathrm{ET}_{c}$ and ranged from $14.7 \mathrm{~kg}$ $\mathrm{ha}^{-1} \mathrm{~mm}^{-1}$ in 2019 (wet year) to $22.7 \mathrm{~kg} \mathrm{ha}^{-1} \mathrm{~mm}^{-1}$ in 2018 . The average seasonal threshold ET ( $x$-intercept) represents the magnitude of the evaporative losses (soil water evaporation and transpiration) for crop establishment before any seed yield is produced (Sinclair et al., 1984; Irmak, 2014). For the local conditions, the threshold ET was estimated to be $171 \mathrm{~mm}$ with substantial interannual variation, with a minimum threshold $\mathrm{ET}_{c}$ of $115 \mathrm{~mm}$ in 2019 to a maximum of $186 \mathrm{~mm}$ in 2018. The IWPF was less consistent than CWPF $\left(\mathrm{R}^{2}=0.73\right.$ for IWPF vs. $\mathrm{R}^{2}=0.92$ for CWPF for pooled data). This difference was primarily due to interannual variability in rainfall distribution and the associated difference in air temperature gradient among the three growing seasons. In addition, the IWPF curves had a lower slope (15.66 kg ha-1 mm${ }^{-1}$ for IWPF vs. $18.89 \mathrm{~kg} \mathrm{ha}^{-1} \mathrm{~mm}^{-1}$ for CWPF for pooled data). This was due to the contribution of soil water storage to $\mathrm{ET}_{c}$ in the deficit irrigation treatments (table 1) and loss of applied irrigation water to $D P$ in the high irrigation treatments (e.g., $D P=20 \mathrm{~mm}$ in 2019 for FIT).

The linear CWPF developed in this study is similar to the CWPF developed by Nielsen (2018). To the best of our

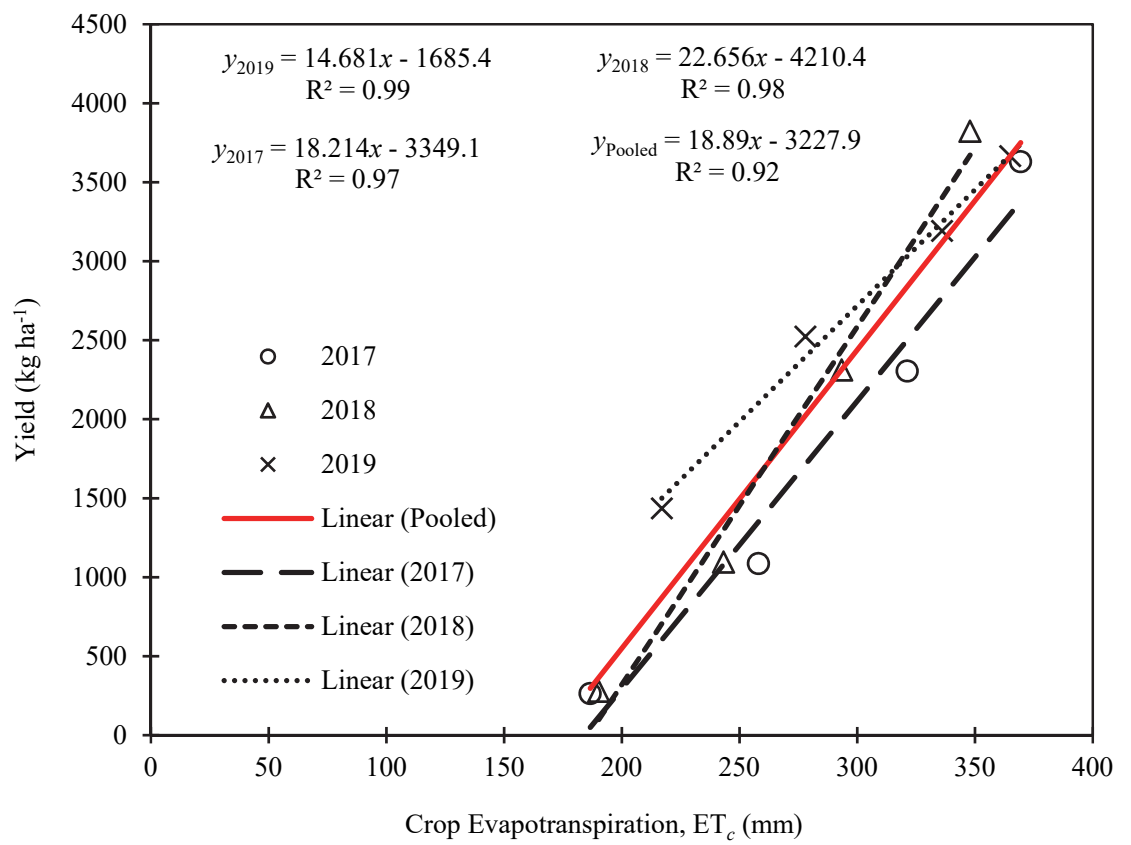

Figure 4. Dry bean yield response to crop evapotranspiration (ET $)$, i.e., crop water production function (CWPF), for all treatments in the 2017, 2018, 2019 growing seasons and pooled data. 
knowledge, no dry bean CWPF has been reported in the literature other than Nielsen (2018). However, to further compare the potential differences in CWPF between this study and other studies, CWPFs were constructed from the published yield and $\mathrm{ET}_{c}$ data for dry bean from Muñoz Perea et al. (2007) and Al-Kaisi et al. (1999) and then compared (fig. 5). The slope of the CWPF obtained in this study was greater than those reported in other studies. For example, Nielsen (2018) developed a CWPF for three different dry bean cultivars (Midnight black bean, Othello pinto bean, and Fisher pinto bean) grown in Weld silt loam soil in the semiarid region of Akron, Colorado, from 1993 to 1998. They used a line-source gradient irrigation system in which the water application amount declined linearly with distance from the irrigation line and reported an average regression slope that varied from $8.86 \mathrm{~kg} \mathrm{ha}^{-1} \mathrm{~mm}^{-1}$ for Midnight black bean to $7.95 \mathrm{~kg} \mathrm{ha}^{-1} \mathrm{~mm}^{-1}$ for Othello pinto bean to $9.82 \mathrm{~kg}$ $\mathrm{ha}^{-1} \mathrm{~mm}^{-1}$ for Fisher pinto bean.

Similar to Nielsen (2018), Muñoz Perea et al. (2007) reported an average CWPF slope of $7.55 \mathrm{~kg} \mathrm{ha}^{-1} \mathrm{~mm}^{-1}$ at the University of Idaho Kimberly Research and Extension Center in 2003 and 2004. They tested three pinto bean and three red bean varieties irrigated with furrow irrigation under nonstressed and drought-stressed conditions. Similarly, lower values of the regression slope than in this study were reported by Al-Kaisi et al. (1999) in southwestern Colorado for dry bean (cv. Bill Z) grown on Wetherill silty clay loam soil and irrigated with a drip system. They reported an average CWPF regression slope of $8.9 \mathrm{~kg} \mathrm{ha}^{-1} \mathrm{~mm}^{-1}$, which varied from $9.6 \mathrm{~kg} \mathrm{ha}^{-1} \mathrm{~mm}^{-1}$ in 1992 to $8.5 \mathrm{~kg} \mathrm{ha}^{-1} \mathrm{~mm}^{-1}$ in 1994.

Differences can also be seen in the threshold $\mathrm{ET}_{c}$ values. For example, Nielsen (2018) reported an average threshold $\mathrm{ET}_{c}$ of $164 \mathrm{~mm}$, which varied from $55 \mathrm{~mm} 1997$ to $389 \mathrm{~mm}$ in 1996 for Othello pinto bean. A lower threshold $\mathrm{ET}_{c}$ of $110 \mathrm{~mm}$ was observed by Muñoz Perea et al. (2007), compared to $171 \mathrm{~mm}$ observed in this study. Those reported differences in CWPF compared to this study may be due to differences in environmental conditions, soil types, experimental methods (i.e., differences in irrigation timing, amount, and method of application), in-season distribution

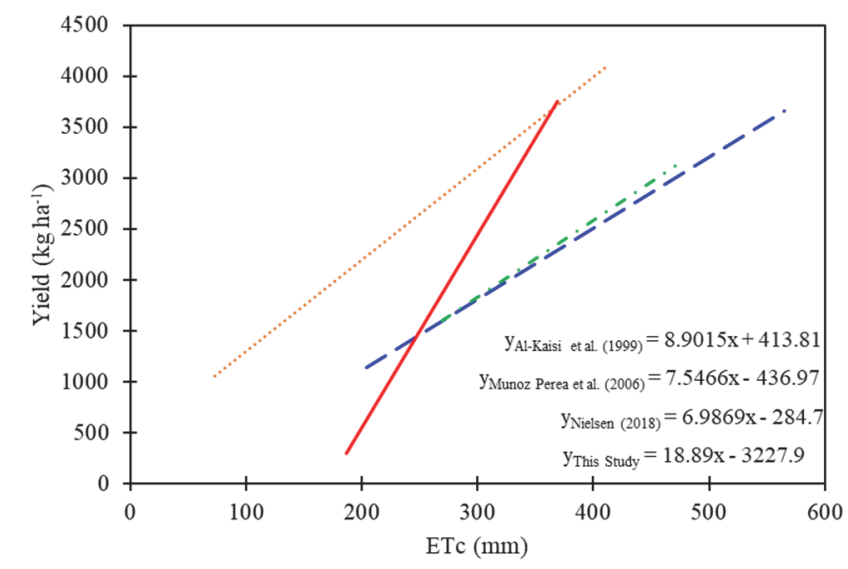

$$
\begin{array}{ll}
\text { - - Linear (Nielsen (2018)) } & \text { …….. Linear (Al-Kaisi et al. (1999)) } \\
\text { - - - Linear (Muñoz Perea et al. (2006) ) } & \quad \text { Linear (This study) }
\end{array}
$$

Figure 5. Comparison of dry bean yield crop water production function (CWPF) developed in this study to CWPFs reported in the literature. of precipitation, hybrid and cultivar, and management practices. The higher threshold $\mathrm{ET}_{c}$ observed in this study provides an opportunity to evaluate different technologies (such as subsurface drip irrigation) and management practices (such as strip-till or no-till) to minimize evaporative losses while maintaining dry bean yield. The IWPF and CWPF developed in this study provide important information needed to maximize the benefits of irrigation. However, improved crop management that encompasses plant breeding and genetic modification, such as better hybrid, variety, and cultivar selection, may result in different CWPF (higher yield with no increase in $\mathrm{ET}_{c}$ ) (Sharma et al., 2016; Irmak and Sharma, 2015).

\section{DRY BEAN YIELD COMPONENT RESPONSE TO IRRIGATION AND CROP ET}

To further investigate the variation in dry bean yield in response to irrigation and crop evapotranspiration, yield component production functions (IYCPF and ETYCPF), i.e., the relationships between yield components (pods per plant, seeds per pod, and 100-seed weight) and cumulative seasonal irrigation (figs. 6a, 6b, and 6c) and between yield components and $\mathrm{ET}_{c}$ (figs. 6d, 6e, and 6f) were developed. To the best of our knowledge, these relationships are some of the first reported in the literature for dry bean. Irrigation amount and crop evapotranspiration significantly affected yield components $(p<0.05)$. A detailed description of the variation in dry bean yield components, the interrelationship between seed yield and yield components, and their relationships with dry bean eco-physiological parameters, i.e., LAI, NDVI, and plant height $(h)$, was presented by Rai et al. (2020). Overall, moderate to high correlations were observed between cumulative irrigation and $\mathrm{ET}_{c}$ with yield components for all growing seasons except for seeds per pod, which was poorly correlated (pooled data $\mathrm{R}^{2}=0.19$ for cumulative irrigation and 0.21 for $\mathrm{ET}_{c}$ ). This was due to significant differences in seeds per pod among the three years. For example, seeds per pod (average of all treatments) was approximately $31 \%$ and $17 \%$ higher for 2019 compared to 2017 and 2018, respectively (fig. 6b). Although no difference in 100-seed weight was observed for 2019 and 2018, the 100 -seed weight for 2017 was approximately $5 \%$ lower compared to 2019 (fig. 6c).

The variation in yield components might have been due to the added heat stress of high daily $T_{\max }$ (number of days with $T_{\max }>30^{\circ} \mathrm{C}$ ) in the vegetation and flowering growth stages in 2017 and 2018, which resulted in a greater negative response in dry bean. High temperature reduces photosynthesis and results in excessive flower drop and pollen sterility due to tapetum degeneration in dry bean, which further reduces the number of pods, seeds per pod, and seed yield (Muñoz-Perea et al., 2007). Masaya and White (1991) showed that temperatures above $28^{\circ} \mathrm{C}$ can cause flower drop, reduction of pollen viability, and abortion of fertilized ovules in common beans. In all three years, yield components increased with irrigation and tended to level off for seasonal irrigation above $264 \mathrm{~mm}$. The ETYCPF developed in this study resulted in linear models with slopes of 0.05 for pods per plant, 0.004 for seeds per pod, and 0.05 for 100 -seed weight per $\mathrm{mm}$ of $\mathrm{ET}_{c}$, respectively. The inclusion of $125 \%$ 

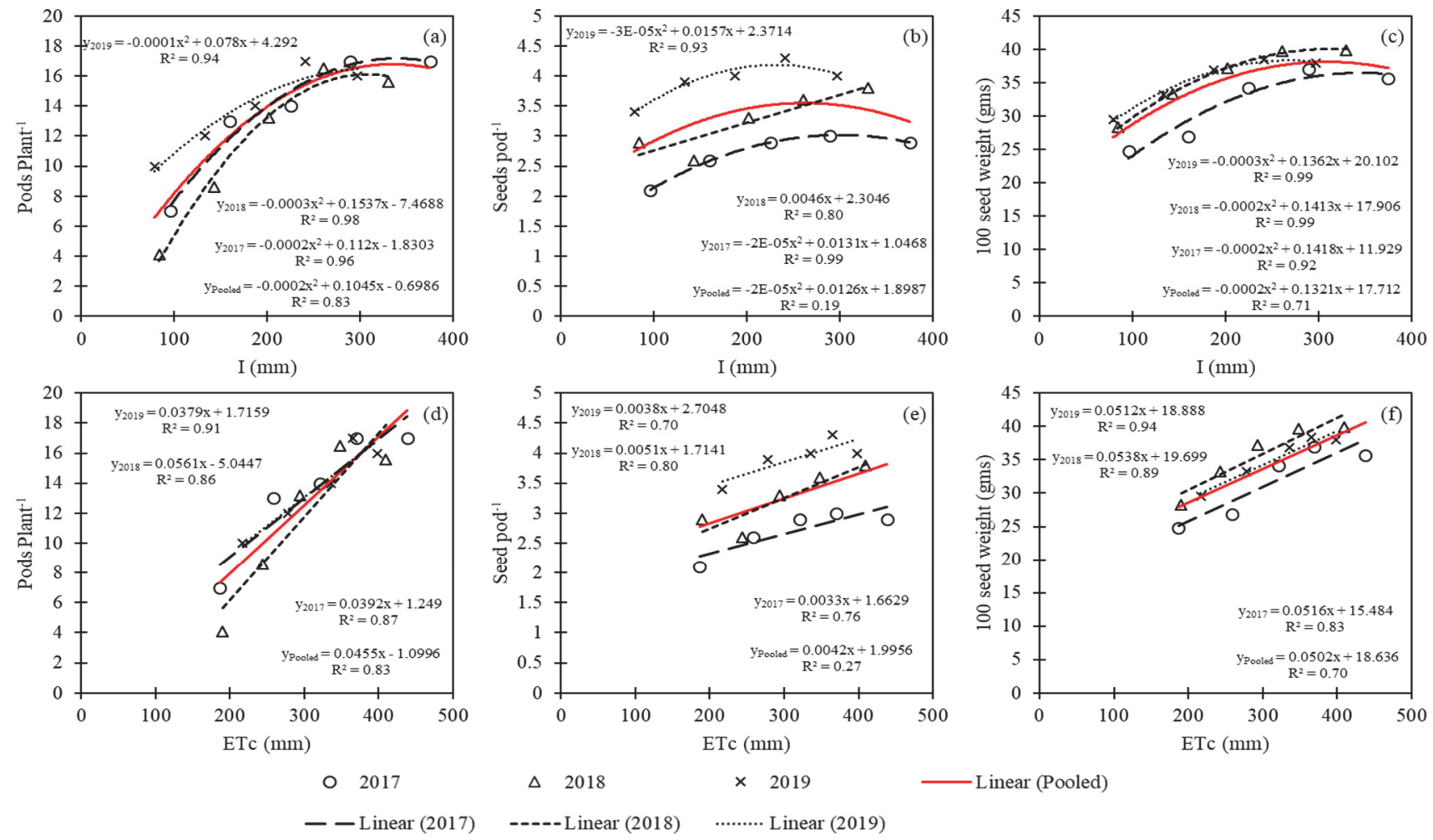

Figure 6. Relationship between dry bean yield components, i.e., pods per plant (left column), seeds per pod (middle column), and 100-seed weight

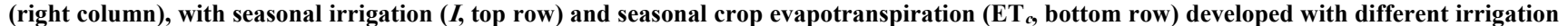
treatments during the 2017,2018 , and 2019 growing seasons.

FIT in ETYCPF indicated that extra ET did not increase any of the measured yield components.

\section{YIELD RESPONSE FACTOR $\left(K_{Y}\right)$}

To analyze the impact of water stress on dry bean yield, the yield response factor $\left(K_{y}\right)$, which is defined by the slope of the relationship between relative yield reduction and relative $\mathrm{ET}_{c}$ (Doorenbos and Kassam, 1979), was calculated for each year and for pooled data (fig. 7). As expected, a linear

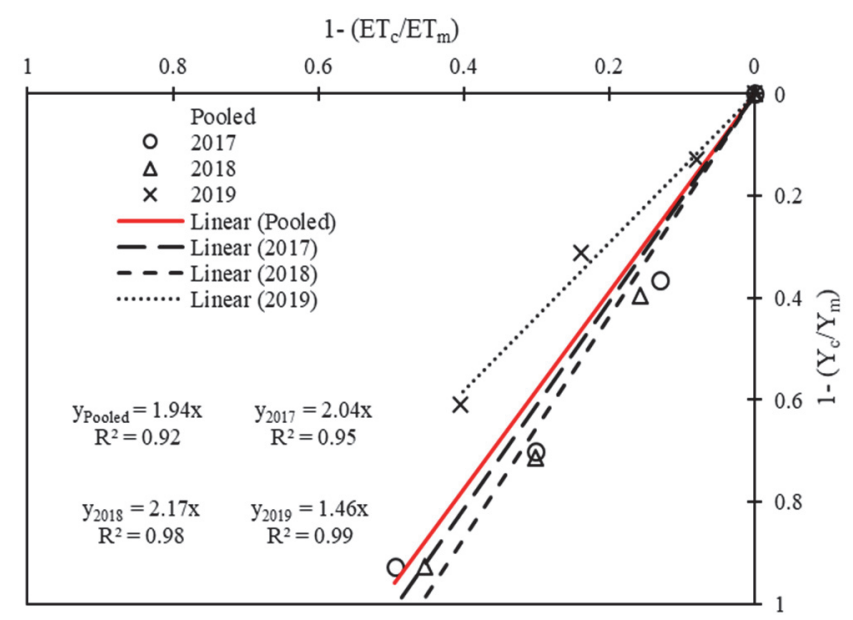

Figure 7. Dry bean yield response factor $\left(K_{y}\right)$, i.e., the relationship between relative evapotranspiration deficit $\left(1-\mathbf{E T}_{c} / \mathbf{E T} T_{m}\right)$ and relative yield deficit $\left(1-Y_{d} / Y_{m}\right)$ for the 2017, 2018, and 2019 growing seasons: $\mathbf{E T}_{c}=$ actual evapotranspiration $(\mathrm{mm}), \mathbf{E T}_{m}=$ maximum evapotranspiration without water stress $(\mathrm{mm}), Y_{c}=$ actual yield $\left(\mathrm{kg} \mathrm{ha}^{-1}\right)$, and $\boldsymbol{Y}_{m}=$ maximum yield without water stress $\left(\mathrm{kg} \mathrm{ha}^{-1}\right)$. reduction in relative yield was observed with increasing relative $\mathrm{ET}_{c}$ deficit, with $K_{y}$ values ranging from 1.46 in 2019 to 2.17 in 2018 , and an average $K_{y}$ of 1.94 with pooled data. The lowest value was observed for the wettest year. This indicated that the imposed water stress was severe, which decreased the dry bean yield by approximately two times more than the relative $\mathrm{ET}_{c}$ deficit. These results indicated that under typical semi-arid to arid climate conditions of the intermountain region of Wyoming, and for regions with similar climate and management practices, deficit irrigation for dry bean may not be a viable strategy because the yield loss likely outweighs the water-saving benefits.

In general, the $K_{y}$ values observed in this study were higher than those reported in previous studies. For example, Doorenbos and Kassam (1979) reported dry bean $K_{y}$ values of 1.15 for the whole growing season. A possible reason for the higher $K_{y}$ values in this study may be the difference in irrigation and crop management. Other than Doorenbos and Kassam (1979), no dry bean $K_{y}$ values are presented in the literature. However, efforts were made to compare the $K_{y}$ values obtained in this study with other seed legumes. For example, in the Mediterranean climate of Turkey, Gençoğlan et al. (2006) reported $K_{y}$ values of 1.55 and 3.54 for green beans under subsurface drip irrigation and alternating subsurface drip irrigation, respectively. Although the irrigation method and management practices were different, the $K_{y}$ values observed in this study compared well with those of Gençoğlan et al. (2006). On the other hand, a $K_{y}$ value of 1.23 was observed by Sezen et al. (2005) for green beans in Turkey. The $K_{y}$ values observed in this study are 
also consistent with the $K_{y}$ values of 2.2 to 2.5 reported by Duzdemir et al. (2009) for peas, indicating that pea seed yield is very sensitive to water stress. This difference in $K_{y}$ values across different regions for dry bean and similar legumes illustrates the dependency of $K_{y}$ on genotype, experimental setup, severity of water stress, and management practices and further justifies the importance of locally developed $K_{y}$ values.

\section{SUMMARY AND CONCLUSIONS}

Dry bean soil moisture dynamics, crop evapotranspiration $\left(\mathrm{ET}_{c}\right)$, irrigation production functions (IWPF), crop water production functions $(\mathrm{CWPF})$, irrigation and $\mathrm{ET}_{c}$ yield component production functions (IYCPF and ETYCPF), and yield response factors $\left(K_{y}\right)$ were quantified through field experiments conducted during the 2017, 2018, and 2019 growing seasons at the University of Wyoming's Powell Research and Extension Center near Powell, Wyoming. The results showed a significant influence of irrigation on dry bean soil moisture dynamics and crop water use. Dry bean is a shallow-rooted crop, and most of the soil moisture dynamics were observed in the top $0.3 \mathrm{~m}$ of the soil profile in the nonstressed treatments. However, in the deficit irrigation treatments, some soil moisture depletion was observed at the 0.6 and $0.9 \mathrm{~m}$ depths for any treatment or growing season. Approximately $41 \%, 47 \%$, and $53 \%$ of total $\mathrm{ET}_{c}$ occurred from planting to flowering in the non-stressed treatments, while the remaining $\mathrm{ET}_{c}$ occurred during flowering and maturation (R5 to harvest) in 2017, 2018, and 2019, respectively.

The relationship between dry bean seed yield and cumulative irrigation water was a two-segment relationship. Under the typical arid to semi-arid conditions of the Big Horn basin, the cumulative seasonal irrigation of $264 \mathrm{~mm}$ produced the maximum seed yield and yield components. Furthermore, a strong relationship between seed yield and $\mathrm{ET}_{c}$ was observed, and seed yield increased linearly with an increase in $\mathrm{ET}_{c}$. On average, a threshold $\mathrm{ET}_{c}$ of $171 \mathrm{~mm}$ was required for crop establishment and to produce seed yield, and any further increase in $\mathrm{ET}_{c}$ increased yield by $18.9 \mathrm{~kg}$ $\mathrm{ha}^{-1} \mathrm{~mm}^{-1}$. The dry bean crops were highly sensitive to water stress $\left(K_{y}=1.94\right)$.

The data collected in this study provide much needed information for dry bean producers and their advisors, state agricultural agencies, and commodity boards (such as the Wyoming Bean Commission and the Nebraska Dry Bean Commission). The data collected in this study are also valuable for developing decision support systems (DSS) and strategies for profitable dry bean production. It is important to note that different cultivars (such as intermediate vs. upright, early maturing vs. late maturing, and drought-sensitive vs. droughtresistant) and management practices (such fertilizer application) also affect crop water productivity. Therefore, further research that includes different cultivars, management practices, and development of DSS for the intermountain region of Wyoming and similar regions with varying production systems can provide further information for long-term and preseason strategic planning for dry bean production.

\section{ACKNOWLEDGEMENTS}

This research was supported by the Wyoming Department of Agriculture, Specialty Crop Block Grant Program (Project No. 1003538) and the USDA National Institute of Food and Agriculture (PI's Hatch Project No. WYO590-18).

\section{REFERENCES}

Al-Kaisi, M. M., Berrada, A. F., \& Stack, M. W. (1999). Dry bean yield response to different irrigation rates in southwestern Colorado. J. Prod. Agric., 12(3), 422-427. https://doi.org/10.2134/jpa1999.0422

Allen, R. G., Pereira, L. S., Raes, D., \& Smith, M. (1998). Crop evapotranspiration: Guidelines for computing crop water requirements. FAO Irrigation and Drainage Paper No. 56. Rome, Italy: United Nations FAO.

ASCE. (2005). Standardized reference evapotranspiration equation. Reston, VA: ASCE Environmental and Water Resources Institute.

Briggs, L. J., \& Shantz, J. L. (1913). The water requirement of plants: II. A review of literature. USDA Bur. Plant Ind. Bulletin No. 285. Washington, DC: USDA Bureau of Plant Industry.

Bryant, K. J., Benson, V. W., Kiniry, J. R., Williams, J. R., \& Lacewell, R. D. (1992). Simulating corn yield response to irrigation timings: Validation of the EPIC model. J. Prod. Agric., 5(2), 237-242. https://doi.org/10.2134/jpa1992.0237

Daryanto, S., Wang, L., \& Jacinthe, P.-A. (2015). Global synthesis of drought effects on food legume production. PLoS One, 10(6), e0127401. https://doi.org/10.1371/journal.pone.0127401

de Wit, C. T. (1958). Transpiration and crop yields. Scientific Report Agric. Res. Rep., 64(6). Retrieved from https://edepot.wur.nl/186445

Djaman, K., \& Irmak, S. (2012). Actual crop evapotranspiration and alfalfa- and grass-reference crop coefficients of maize under full and limited irrigation and rainfed conditions. J. Irrig. Drain. Eng., 139(6), 433-446. https://doi.org/10.1061/(ASCE)IR.19434774.0000559

Doorenbos, J., \& Kassam, A. H. (1979). Yield response to water. FAO Irrigation and Drainage Paper No. 33. Rome, Italy: United Nations FAO. https://doi.org/10.1016/B978-0-08-0256757.50021-2

Dubois, O. (2011). The state of the world's land and water resources for food and agriculture: Managing systems at risk. London, UK: Earthscan. Retrieved from http://www.fao.org/3/i1688e/i1688e03.pdf

Duzdemir, O., Kurunc, A., \& Unlukara, A. (2009). Response of pea (Pisum sativum) to salinity and irrigation water regime. Bulgarian J. Agric. Sci., 15(5), 400-409.

Emam, Y., Shekoofa, A., Salehi, F., Jalali, A. H., \& Pessarakli, M. (2012). Drought stress effects on two common bean cultivars with contrasting growth habits. Archives Agron. Soil Sci., 58(5), 527-534. https://doi.org/10.1080/03650340.2010.530256

English, M. (1990). Deficit irrigation: I. Analytical framework. $J$. Irrig. Drain. Eng., 116(3), 399-412. https://doi.org/10.1061/(ASCE)0733-9437(1990)116:3(399)

Gençoğlan, C., Altunbey, H., \& Gençoğlan, S. (2006). Response of green bean $(P$. vulgaris L.) to subsurface drip irrigation and partial rootzone-drying irrigation. Agric. Water Mgmt., 84(3), 274-280. https://doi.org/10.1016/j.agwat.2006.02.008

Giorgi, F., \& Bi, X. (2005). Updated regional precipitation and temperature changes for the 21 st century from ensembles of recent AOGCM simulations. Geophys. Res. Lett., 32(21). https://doi.org/10.1029/2005GL024288 
Howell, T. A., \& Hiler, E. A. (1975). Optimization of water use efficiency under high-frequency irrigation: I. Evapotranspiration and yield relationship. Trans. ASAE, 18(5), 873-878. https://doi.org/10.13031/2013.36700

Howell, T. A., Tolk, J. A., Schneider, A. D., \& Evett, S. R. (1998). Evapotranspiration, yield, and water use efficiency of corn hybrids differing in maturity. Agron. J., 90(1), 3-9. https://doi.org/10.2134/agronj1998.00021962009000010002x

Irmak, S. (2014). Interannual variation in long-term center pivotirrigated maize evapotranspiration and various water productivity response indices: I. Grain yield, actual and basal evapotranspiration, irrigation-yield production functions, evapotranspiration-yield production functions, and yield response factors. J. Irrig. Drain. Eng., 141(5), 04014068. https://doi.org/10.1061/(ASCE)IR.1943-4774.0000825

Irmak, S., \& Sharma, V. (2015). Large-scale and long-term trends and magnitudes in irrigated and rainfed maize and soybean water productivity: Grain yield and evapotranspiration frequency, crop water use efficiency, and production functions. Trans. ASABE, 58(1), 103-120.

https://doi.org/10.13031/trans.58.10784

Jacobs, J. J., \& Brosz, J. D. (1995). Wyoming water law: A summary. B-849R. Laramie, WY: University of Wyoming, Cooperative Extension Service.

Ji, S., \& Unger, P. W. (2001). Soil water accumulation under different precipitation, potential evaporation, and straw mulch conditions. SSSA J., 65(2), 442-448. https://doi.org/10.2136/sssaj2001.652442x

Kang, S., Zhang, L., Liang, Y., Hu, X., Cai, H., \& Gu, B. (2002). Effects of limited irrigation on yield and water use efficiency of winter wheat in the Loess Plateau of China. Agric. Water Mgmt., 55(3), 203-216. https://doi.org/10.1016/S0378-3774(01)00180-9

Kirda, C., Kanber, R., \& Tulucu, K. (1999). Yield response of cotton, maize, soybean, sugar beet, sunflower, and wheat to deficit irrigation. In Crop yield response to deficit irrigation (pp. 21-38). Dordrecht, Netherlands: Kluwer Academic.

Klocke, N. L., Currie, R. S., Kisekka, I., \& Stone, L. R. (2014). Corn and grain sorghum response to limited irrigation, drought, and hail. Appl. Eng. Agric., 30(6), 915-924. http://doi.org/10.13031/aea.30.10810

Kuscu, H., Karasu, A., Mehmet, O. Z., Demir, A. O., \& Turgut, I. (2013). Effect of irrigation amounts applied with drip irrigation on maize evapotranspiration, yield, water use efficiency, and net return in a sub-humid climate. Turkish J. Field Crops, 18(1), 1319.

Lanna, A. C., Mitsuzono, S. T., Terra, T. G., Pereira Vianello, R., \& Carvalho, M. A. D. F. (2016). Physiological characterization of common bean (Phaseolus vulgaris L.) genotypes, water-stress induced with contrasting response towards drought. Australian J. Crop Sci., 10(1), 1-6.

Masaya, P., \& White, J. W. (1991). Adaptation to photoperiod and temperature. In Common beans: Research for crop improvement (pp. 445-500). Cali, Colombia: Centro Internacional de Agricultura Tropical (CIAT).

Miller, D. E., \& Burke, D. W. (1983). Response of dry beans to daily deficit sprinkler irrigation. Agron. J., 75(5), 775-778. https://doi.org/10.2134/agronj1983.00021962007500050013x

Muñoz-Perea, C. G., Allen, R. G., Westermann, D. T., Wright, J. L., \& Singh, S. P. (2007). Water use efficiency among dry bean landraces and cultivars in drought-stressed and non-stressed environments. Euphytica, 155(3), 393-402.

https://doi.org/10.1007/s10681-006-9340-z

Nielsen, D. C. (2018). Dry bean water use/yield production function to estimate dryland yields in the U.S. Central High Plains. Field Crops Res., 228, 60-67. https://doi.org/10.1016/j.fcr.2018.08.016
Nielsen, D. C., \& Nelson, N. O. (1998). Black bean sensitivity to water stress at various growth stages. Crop Sci., 38(2), 422-427. https://doi.org/10.2135/cropsci1998.0011183X003800020025x

Nuñez Barrios, A., Hoogenboom, G., \& Nesmith, D. S. (2005). Drought sress and the distribution of vegetative and reproductive traits of a bean cultivar. Scientia Agricola, 62(1), 18-22.

Payero, J. O., Melvin, S. R., Irmak, S., \& Tarkalson, D. (2006). Yield response of corn to deficit irrigation in a semiarid climate. Agric. Water Mgmt., 84(1), 101-112. https://doi.org/10.1016/j.agwat.2006.01.009

Payero, J. O., Tarkalson, D. D., Irmak, S., Davison, D., \& Petersen, J. L. (2009). Effect of timing of a deficit-irrigation allocation on corn evapotranspiration, yield, water use efficiency, and dry mass. Agric. Water Mgmt., 96(10), 1387-1397. https://doi.org/10.1016/j.agwat.2009.03.022

Pereira, L. S., Oweis, T., \& Zairi, A. (2002). Irrigation management under water scarcity. Agric. Water Mgmt., 57(3), 175-206. https://doi.org/10.1016/S0378-3774(02)00075-6

Rai, A., Sharma, V., \& Heitholt, J. (2020). Dry bean (Phaseolus vulgaris $\mathrm{L}$.) growth and yield response to variable irrigation in the arid to semi-arid climate. Sustainability, 12(9), article 3851. https://doi.org/10.3390/su12093851

Ramirez-Vallejo, P., \& Kelly, J. D. (1998). Traits related to drought resistance in common bean. Euphytica, 99(2), 127-136. https://doi.org/10.1023/A:1018353200015

Schwartz, H. F., \& Brick, M. A. (Eds.) (2015). Dry bean production and pest management (3rd Ed.). Fort Collins, CO: Colorado State University, Cooperative Extension Resource Center.

Sezen, S. M., Yazar, A., Canbolat, M., Eker, S., \& Cęlikel, G. (2005). Effect of drip irrigation management on yield and quality of field-grown green beans. Agric. Water Mgmt., 71(3), 243-255. https://doi.org/10.1016/j.agwat.2004.09.004

Sharma, V., Irmak, S., Djaman, K., \& Sharma, V. (2016). Largescale spatial and temporal variability in evapotranspiration, crop water-use efficiency, and evapotranspiration water-use efficiency of irrigated and rainfed maize and soybean. J. Irrig. Drain. Eng., 142(3), article 04015063

Sharma, V., Nicholson, C., Bergantino, A., Irmak, S., \& Peck, D. (2020). Temporal trend analysis of meteorological variables and reference evapotranspiration in the inter-mountain region of Wyoming. Water, 12(8), article 2159. https://doi.org/10.3390/w12082159

Sharma, V., Nicholson, C., Bergantino, T., Cowley, J., Hess, B., \& Tanaka, J. (2018). Wyoming Agricultural Climate Network (WACNet). In 2018 Field Days Bulletin (pp. 52-53). Laramie, WY: University of Wyoming, Agricultural Experiment Station.

Shrestha, N., Geerts, S., Raes, D., Horemans, S., Soentjens, S., Maupas, F., \& Clouet, P. (2010). Yield response of sugar beets to water stress under western European conditions. Agric. Water Mgmt., 97(2), 346-350.

https://doi.org/10.1016/j.agwat.2009.10.005

Sinclair, T. R., Tanner, C. B., \& Bennett, J. M. (1984). Water use efficiency in crop production. BioScience, 34(1), 36-40. https://doi.org/10.2307/1309424

Singh, S. P., Terán, H., Muñoz-Perea, C. G., Lema, M., Dennis, M., Hayes, R., ... Smith, J. (2009). Dry bean landrace and cultivar performance in stressed and nonstressed organic and conventional production systems. Crop Sci., 49(5), 1859-1866. https://doi.org/10.2135/cropsci2008.10.0578

Singh, Y., Rao, S. S., \& Regar, P. L. (2010). Deficit irrigation and nitrogen effects on seed cotton yield, water productivity, and yield response factor in shallow soils of semi-arid environment. Agric. Water Mgmt., 97(7), 965-970. https://doi.org/10.1016/j.agwat.2010.01.028

Spurgeon, W. E., \& Dean Yonts, C. (2013). Water productivity of corn and dry bean rotation on very fine sandy loam soil in 
western Nebraska. Appl. Eng. Agric., 29(6), 885-892. https://doi.org/10.13031/aea.29.9872

Stewart, J. I., \& Hagan, R. M. (1973). Functions to predict effects of crop water deficits. J. Irrig. Drain. Div., 99(4), 421-439. https://doi.org/10.1061/JRCEA4.0000948

Stoker, R. (1974). Effect on dwarf heans of water stress at different phases of growth. New Zealand J. Exp. Agric., 2(1), 13-15. https://doi.org/10.1080/03015521.1974.10427662

Terán, H., \& Singh, S. P. (2002). Comparison of sources and lines selected for drought resistance in common bean. Crop Sci., 42(1), 64-70. https://doi.org/10.2135/cropsci2002.6400

Trout, T. J., \& DeJonge, K. C. (2017). Water productivity of maize in the U.S. High Plains. Irrig. Sci., 35(3), 251-266. https://doi.org/10.1007/s00271-017-0540-1

Trout, T. J., Howell, T. A., English, M. J., \& Martin, D. L. (2020). Deficit irrigation strategies for the western U.S. Trans. ASABE, 63(6), 1813-1825. https://doi.org/10.13031/trans.14114
USDA-NASS. (2018). Irrigation and water management survey. Washington, DC: USDA National Agricultural Statistics Service.

USDA-SCS. (1985). National engineering handbook (NEH): Section 4, hydrology. Washington, DC: USDA Soil Conservation Service.

Wilhite, D. A., Svoboda, M. D., \& Hayes, M. J. (2007). Understanding the complex impacts of drought: A key to enhancing drought mitigation and preparedness. Water Resour. Mgmt., 21(5), 763-774. https://doi.org/10.1007/s11269-0069076-5

Yonts, C. D., Haghverdi, A., Reichert, D. L., \& Irmak, S. (2018). Deficit irrigation and surface residue cover effects on dry bean yield, in-season soil water content, and irrigation water use efficiency in western Nebraska High Plains. Agric. Water Mgmt., 199, 138-147.

https://doi.org/10.1016/j.agwat.2017.12.024 